\title{
Working in Long-Term Residential Care: A Qualitative Metasummary Encompassing Roles, Working Environments, Work Satisfaction, and Factors Affecting Recruitment and Retention of Nurse Aides
}

\author{
Elizabeth Andersen RN BTSN MN \\ Clinical Associate, Faculty of Nursing, University of British Columbia (Okanagan) \\ 3333 University Way, Kelowna, British Columbia, V1V 1V7, Canada \\ Tel: 250-764-0939 E-mail: eaa@ualberta.ca
}

\begin{abstract}
By means of the Cumulative Index to Nursing and Allied Health Literature (CINAHL), MEDLINE, EMBASE and Ageline (AARP) database searches, the author presents a review of the literature addressing residential care aides- their roles, working environments, work satisfaction, and factors affecting recruitment and retention. Using the method of qualitative metasummary, eight broad themes emerged: job dissatisfaction, low wages, attrition and retention difficulties, threats to personal safety, the experience of hierarchy (devaluation and domination), the importance of relationships and collegial support, excessive workloads and inadequate training. Heavy reliance on American research is a limitation, but there appears to be general agreement across eight countries that residential care aide work can be arduous, demanding and demoralizing. At the same time, given the constraints that most aides work under, many aides care greatly about their clients and are very concerned about the quality of care that they are able to provide. Their voices, however, remain relatively overlooked or ignored.
\end{abstract}

Keywords: Nurse Aide, Metasummary, Role, Work environment, Work satisfaction, Recruitment, Retention, Long term care

\section{Background}

Over the past three decades, Canada has experienced a dramatic increase in the number of persons living beyond age 65 . In 2000, life expectancy at age 65 reached 16.8 years for males and 20.5 years for females, an increase of 0.3 years and 0.2 years respectively compared with 1999 (Statistics Canada, 2002, p.52). By the year 2030, Canada's aging population is predicted to form nearly one-quarter of Canada's entire population (Statistics Canada, 2002). The change in life expectancy is anticipated to bring many economic, social, political and health care challenges but the greatest of these will be the challenge to provide quality long term nursing care to the increasing population of persons who will require it. Over the past decade, there have been dramatic shifts in staffing patterns in long term care facilities in Canada and in other countries. Nurse aides are being employed in escalating numbers. In Canada, this increase is said to be related to three important factors: the need to control health care costs, a current and projected shortage of regulated health care professionals and an ageing population which requires new approaches to health-care delivery (Canadian Nurses Association-CNA, 2008, p. 2). In the United States, aides now provide $90 \%$ of the care to residents who live in long term care facilities (Castle, 2007; Friedman, Daub, Cresci, \& Keyser, 1999; Riggs, \& Rantz, 2001).

In long term care institutions, aides provide basic resident care. This includes but is not limited to answering calls for assistance, assisting in all activities of daily living (bathing, dressing and grooming, serving meals and feeding residents), taking measurements such as resident's weight, blood pressure, temperature and pulse, collecting urine and stool specimens, administering suppositories and enemas, administering non prescription medications, emptying ostomies and catheters, applying prosthetics or orthotics, assisting with oxygen equipment, assisting with bi-level positive airway pressure (BIPAP) or continuous positive airway pressure (CPAP), and care of a body after death (BC Ministry of Health, 2007; Work Futures BC, 2005).

\section{Purpose}

The purpose of this qualitative metasummary is to expose tensions, map diversity and communicate the complexity of how different research traditions and investigators from different countries have contributed to our understanding of nurse aides as a whole (Greenhalgh et al., 2005, p. 427). 


\section{Qualitative Metasummary}

Qualitative metasummary (also known as mixed research synthesis) is a technique developed by Sandelowski, Barroso and Voils (2007). Initially, the method was used exclusively to review and summarize qualitative findings presented in the form of surveys. In contrast to solely descriptive literature reviews, these qualitative metasummaries were analytical as well as descriptive. They reflected "a quantitative logic" (p.101) because the authors would assess the relative magnitude of each abstracted finding and then arrange and present all abstracted findings in a mathematical manner.

Throughout the process of completing several qualitative metasummaries, Sandelowski et al. observed that lists contained in qualitative reports were very similar "in form (and)...the degree of interpretation" (p.102) to lists offered in quantitative studies. In addition, the authors observed fewer "methodological differences (between qualitative and quantitative) than might be expected" (p.103). Although qualitative and quantitative studies are widely viewed as dissimilar with regards to sampling, the same authors became aware that the samples in qualitative and quantitative reports often converged in the homogeneity of composition (p.103). Therefore, they expanded their technique to include synthesis of both qualitative and quantitative reports.

The method of qualitative metasummary appears to be particularly appropriate for a review of the literature concerning nurse aides: First, the literature is mixed but predominantly quantitative. Second, the qualitative studies rely heavily on surveys or questionnaires. Third, both qualitative and quantitative studies converge in the homogeneity of the sample composition:

- $\quad$ more than $90 \%$ of all nurse aides world wide are women

- the majority of the studies about nurse aides report that the aides belong to minority groups

- $\quad$ the majority of all nurse aides world wide belong to low or lower middle income categories.

\section{Method}

\subsection{Extraction}

Each metasummary begins with a comprehensive search using multiple strategies. For this metasummary, the electronic databases CINAHL (1982 to present), MEDLINE (1966 to present), EMBASE (1988 to present) and AARP (1978 to present) were searched using a combination of the different titles used to represent nurse aides namely: residential care attendant, certified nursing assistant, personal care aide/worker, geriatric aide, residential care aide, nurse aide, and personal support aide/worker. Searches were restricted to English language articles. Unpublished dissertations were excluded. Forty-six journal articles were identified at first. A separate search of key journals followed, and a 'snowball' search of references contained within all previously obtained empirical papers completed the process. A total of 138 articles and eight trade or organizational reports published between 1983 and 2007 were sampled in this way.

Of these, 16 were published in the 1980s, 60 were published in the 1990s and 68 were published from 2000 onwards. One hundred and four articles were written by American authors, 15 articles were British, thirteen were Canadian, two were Australian, five were Swedish, one was Dutch, four articles were from Taiwan and two were from the Netherlands. Twenty-six were qualitative studies, 72 were quantitative studies, six were mixed methods, ten were literature reviews and 23 were descriptive or opinion papers (including articles theorizing about the practice or modeling the practice of nurse aides). For the full contribution (origin, authors, date, methods and findings) of the different sources to the final metasummary, please refer to Table One.

In a qualitative metasummary, the bias is towards inclusion and not exclusion of reports (Sandelowski et al. 2007) therefore no report was excluded because my own "paradigmatic lens" directed me to an 'obvious' body of literature with a preferred methodology (Greenhalgh et al., 2005, p.427).

\subsection{Abstraction and Grouping}

After an initial reading each primary source was annotated (reduced to a single page or less of single spaced type). This approach facilitated systematic comparison of specific issues, variables or sample characteristics (Whittemore \& Knafl, 2005). The next step was "data display" (Whittemore \& Knafl, 2005, p. 551). The annotations were grouped by gathering comparable studies together which allowed for "visualization of patterns and relationships within and across primary data sources (and) a starting point for interpretation" (p.551). The data display (abstraction and grouping) follows (See Table 2.).

Sandelowski et al. (2007) caution that every metasummary is subjective and negotiable because at every stage of a review, judgements have to be made regarding "what constitutes a finding, which findings are unique enough to be listed separately, which findings are similar enough to be grouped together, and what categories (they) represent" (p.109). 


\subsection{Calculating Frequency Effect Sizes}

To assess the relative magnitude of the abstracted findings, the frequency effect size was calculated by "taking the number of reports containing a finding (minus any reports derived from a common parent study and representing a duplication of the same finding) and dividing this number by the total number of reports (minus any reports derived from a common parent study and representing a duplication of the same finding)" (Sandelowski et al, p.107). Frequency effect size "moves the interpretive effort from the description of patterns and relationships to higher levels of abstraction" (Whittemore \& Knafl, 2005, p.551). (See Table 3.).

\section{Interpretation of Synthesis Results}

Eight broad themes emerged from the metasummary: job dissatisfaction, low wages, attrition and retention difficulties, threats to personal safety, the experience of hierarchy (devaluation and domination), the importance of relationships and collegial support, excessive workloads and inadequate training.

\subsection{Job Dissatisfaction}

Researchers in 25 studies investigated various aspects of job satisfaction. Of these studies 18 were American. In general, investigators observed that organizational factors, the working environment, facility characteristics, the supervisory style, and the aide's feelings or beliefs all influence the degree to which care aides are satisfied with their jobs.

Multiple factors seem to promote job dissatisfaction, such as sharp divisions of labour (Grau \& Wellin, 1992), inadequate staffing levels (Beck, Ortigara, Mercer, \& Shue, 1999), traditional bureaucratic organizational structure (Riggs \& Rantz), dismissive, demeaning supervisors (Bowers, Esmond, \& Jacobson, 2003) and lack of rewards for performance (Anderson, Bailey, Corazzini \& Piven, 2005). In addition, investigators point to the fact that aides often feel undervalued and unappreciated by their supervisors and perceive that their efforts are unrecognized (Ahmed \& Kitson, 1993; Dewar \& McCleod-Clark, 1992; Jervis, 2002a).

Aides collectively feel dissatisfied with rigid care routines and time constraints that inhibit them from providing personalized care (Brannon, Streit, \& Smyer, 1992; Krovach \& Krejci, 1998). They complain that they are not listened to (Moyle, Skinner, Rowe, \& Gork, 2003); they complain that they are not involved in the care planning process (Beck et al. 1999); they complain that they are unable to make changes or improvements that they feel would benefit the residents because they lack any decision-making authority (Parson, Simmons, Penn, \& Furlough, 2003; Monahan \& McCarthy, 1992).

Burdened by minimal supervision coupled with inadequate information (Eaton, 2000) and a heavy workload (Chappell \& Novak, 1992), some aides break rules out of desperation (Bowers \& Becker, 1992). Others bundle tasks to accomplish several tasks at once but feel guilty about it (Bowers, Esmond, \& Jacobson, 2000).

\subsection{Low Wages}

Lack of financial compensation also shapes general job dissatisfaction in the United States, where wages are less than a living wage and not competitive with the fast food industry (Harrington et al. 2003). Many American aides work extra shifts or have a second job just to cover basic expenses (Mercer, Heacock, \& Beck, 1993). Some nurse aides set firm boundaries on their work: "I will do no more and no less. I'm not going up and above my way because y'all ain't gonna pay me for it" (quote from aide, Jervis, 2002a, p.19). Low wages are associated with high turnover rates (Banaszak-Holl \& Hines, 1996; Bowers et al. 2000; Caudill \& Patrick, 1989; Harrington \& Swan, 2003) and reduced quality of care (Jervis, 2002a). In some studies, approximately 17-20\% of nurse aides report an intention to quit (Broughton \& Golden, 1995; Caudill \& Patrick, 1989). Harrington et al. (2003) reported that the average annual turnover rate for aides in the US in 2001 was 78\%. Concern about low wages is not limited to American aides. In Taiwan, the monthly wage is also less than service industries (Hsieh \& Su, 2007). In Mexico, the average salary per day is just adequate for necessities (Douglas, Meleis, Eribes, \& Kim, 1996). In Canada wages vary between provinces. In British Columbia, aides currently earn \$19.73 per hour (as per the Hospital Employees Union Facilities Subsector Wage Schedule, 2008).

\subsection{Attrition and Retention Difficulties}

Care aides who leave blame inadequate staffing levels, excessive work loads, lack of training and lack of problem-solving skills necessary to cope with demands (Ahmed \& Kitson, 1993; Beck et al. 1999; Lin, Yin, \& Li, 2002; Riggs \& Rantz, 2001). Aides often feel alone, unsupported and inadequately informed about the residents' conditions (Ahmed \& Kitson, 1993; Anderson et al. 2005; Barney, 1983; Jervis, 2002b). Foner (1994) described the everyday work of nurse aides as physically straining and emotionally wearing. Other authors have characterized the work as routine, repetitive and of low complexity (Brannon, Cohn, \& Smyer, 1990; Brannon et al. 1992). The sheer physical effort of lifting and bathing multiple fragile and often immobile patients is combined with constant noise (Kristiansen, Hellzen, \& Asplund, 2006), multiple, simultaneous demands (Eaton, 2000) and frequent, wide ranging complaints from residents and/or their families (Grau \& Wellin, 1992; Secrest, Iorio, \& Martz, 2005). 
Care aides who stay employed cite being around elderly people - helping and caring for them, being part of a team, feeling valued and needed by the residents and feeling virtuous as motivational factors (Berdes \& Eckert, 2001; Douglas et al. 1996; Hsieh \& Su, 2007; Kristiansen et al. 2006). Research also indicates that caring relationships between aides and residents or aides and families, and collegial connections are very important motivational factors that reduce turnover rates and increase quality of care (Bowers et al. 2000; Brannon et al. 1990; Grau, Chandler, Burton, \& Kolditz, 1991; Parsons et al. 2003). Several investigators found that a uniform culture (religious, ethnic, social and/or economic) between residents/families and staff contributes to harmony and/or decreased staff turnover (Berdes \& Eckert, 2001; Foner, 1994; Grau \& Wellin, 1992; Jervis, 2002a). Satisfied aides feel respected and supported (Grau et al. 1991; Friedman et al. 1999). They believe that they are competent and that they are able to affect residents (Parsons et al. 2003).

In summary, care aides who stay are more likely to be older (Cotton \& Tuttle, 1986) and of the same social, cultural, religious or ethnic background as the residents and their families (Grau \& Wellin, 1992). They become involved in care planning and decision-making (Banaszak-Holl \& Hines, 1996; Broughton \& Golden, 1995; Friedman et al. 1999) and they are more likely to feel that their contributions are valued and acknowledged by the residents, families and supervisors (Broughton \& Golden, 1995). As a consequence, they feel that they are able to provide care in a way that is like family (Bowers et al. 2000). Feelings more strongly determine whether aides are dissatisfied than the more objective features of the job (Grieshaber, Parker, \& Deering, 1995).

Although low turnover rates may appear desirable, the metasummary also revealed that very low turnover rates are undesirable. Some aides stay precisely because middle management is lacking or the supervisors are untrained (Brannon, Zinn, Mor, \& Davis, 2002). Other aides stay because they have become demoralized and have developed a cynical and callous detachment to the job (Tellis-Nayak \& Tellis-Nayak, 1989).

\subsection{Threats to Personal Safety}

There are major concerns in the literature about violence and aggression in the workplace posing a threat to the personal safety of the care aide. Nineteen articles focused specifically on nurse aides' experiences of assault by residents in long term care. Many other articles mentioned assault as a source of stress. The subject of assault is delicate one. Multiple authors describe residents who are bitter and hostile towards the aides (Brodaty, Draper, \& Low, 2003; Foner, 1994; Gates, Fitzwater, \& Succop, 2003; Kristiansen et al. 2006; Ramirez, Teresi, \& Holmes, 2006). Psychological aggression such as shouting, name calling, threats and inappropriate sexual remarks have been found to be significantly related to nurse aides' feelings of reduced personal accomplishment and feelings of emotional exhaustion (Evers, Tomic, \& Brouwers, 2002; Ramirez et al. 2006). These authors suggest that caregivers who experience aggressive behaviour feel isolated and demoralized. Several authors describe how residents or family members make demeaning racist remarks to aides (Berdes \& Eckert, 2001; Foner, 1994; Mercer et al. 1993) or treat aides as servants (Grau \& Wellin, 1992).

On top of this, aides endure physical violence (Burgio, Jones, Butler, \& Engel, 1988; Foner, 1994; Freyne \& Wrigley, 1996; Gates et al. 2003; Kristiansen et al. 2006). More than half of all aides report receiving an injury from a resident at some point during their employment (Fitzwater \& Gates, 2002). The experiences of physical assault include being squeezed against a wall, pinched, scratched, spat at, hunted, hit or having objects thrown towards a person (Burgio et al. 1988; Kristiansen et al. 2006). "It is not little...not small smacks we get. They are in fact quite heavy punches and pinches and bruises.... There are times when you want to scream for help" (quotes from support workers, Kristiansen et al. 2006, p. 248-249). These authors found that physical assault "was regarded as a very trying and unpleasant part of the job" (p.248) and resulted in feelings of humiliation.

Whether physical or verbal assault is intentional or not, many nurse aides regard it as violence (Gates et al. 2003) and sometimes view the residents' aberrant behaviour as deliberate (Brodaty et al. 2003). These same authors concluded that nursing home staff generally perceive residents in more negative ways than positive ways.

\subsection{The Experience of Hierarchy: Devaluation and Domination}

Most care aides are employed in highly structured, complex, hierarchical systems that resist change. A number of studies report very distressing findings of nurse aides' perceptions of hierarchies, leading to devaluation and domination (Helmer, Olsen, \& Heim, 1993; Jervis, 2002a; Kristiansen et al. 2006). Nurse aides have been found to have feelings of humiliation, vulnerability, insignificance, invisibility, uncertainty and insecurity (Dewar \& McCleod-Clark, 1992; Kristiansen et al. 2006). Kristiansen et al. (2006) refer to the "employer's meta message" (p.252) which is interpreted by nurse aides as "not feeling valued" or "confirmed" by their employer (p.252). The same authors refer to a gap "between the current economic and moral reality and the ideal moral desire, resulting in nurse aides' awareness of their own feelings of inadequacy and failure" (p.252).

Jervis (2002a) explored the relationships among nurses and nurse aides in an urban nursing home in the United States and found a militaristic paradigm for staff organization in which nurse aides served as subordinates. Nurse aides were assigned rank-specific duties and were held accountable to individuals higher in the staff hierarchy. In describing this 
hierarchy, one staff member utilized a feudal system metaphor: "Nursing homes are like little principalities. You've got your royalty, your minor nobility, and your peasants. Everybody is trying to get in with the royalty and the peasants are getting screwed" (quote from staff member, Jervis, 2002a, p.14). The administration's embrace of hierarchy was reflected in their choice of words such as "delegate down" and "down at the unit level" (p.14).

\subsection{The Importance of Collegial Support}

Generally, nurse aides express strong feelings of mutuality with their co-workers. "My work-mates are the most positive thing about working here...you are never alone" (quote from support worker, Kristiansen et al. 2006, p.251). Job tasks and job process are less important to institutional loyalty than the warmth, friendliness, support and caring of co-workers and superiors (Brannon et al. 1990; Grau et al. 1991). "If it wasn't for these nurses aides socializing with one another, somebody would crack" (Quote from nurse aide, Jervis, 2002a, p. 18).

\subsection{Excessive Workload}

There is not enough time in the day for nurse aides to get everything done (Bowers et al. 2000; Krovach \& Krejci, 1998). Workload is affected by a high ratio of residents to aides or a high acuity level of the residents (Garland, Oyabu, \& Gipson, 1988; Mercer et al. 1993). Time saving measures include not allowing the resident to choose clothing, hurrying their dressing, cutting back on grooming, eliminating oral care and abbreviating the bath (tops and tails only) (Bowers et al. 2000). "They'll get washed up, they're kept dry and turned over, but they don't get lotion, they don't get the one on ones, they don't get walks" (quote from aide, Bowers et al. 2000, p.60). Inadequate equipment or lack of supplies also prevents aides from doing their job effectively (Garland, Oyabu, \& Gipson, 1989; Mercer, Heacock, \& Beck, 1994). Experienced aides find ways to get the job done by integrating demands, maximizing efficiency through organization and knowing when to safely cut corners (Bowers \& Becker, 1992).

\subsection{Inadequate Training}

Three quarters of all aides feel inadequately trained for the job (Mercer et al. 1993). Due to heavy workloads and time constraints, aides receive varied and limited orientations and limited in-service education (Banaszak-Holl \& Hines, 1996; Eaton, 2000; Lin et al. 2002).

It has been well documented that most aides lack basic mental health training and the skills to understand and manage challenging behaviours (Evers, Tomic, \& Brouwers, 2002: Feldt \& Ryden, 1992; Grant, Kane, Potthoff, \& Ryden, 1996; Teresi, Holmes, Ramires, \& Kong, 1998). Aides may experience exhaustion, tension and burn-out due to turmoil and disruption (Chappell \& Novak, 1994; Dougherty, Bolger, Preston, Jones, \& Payne, 1992).

In the United States, a 75 hour training course and certification testing is federally mandated (Castle, Engberg, Anderson, \& Men, 2007), although some states (for example, California) require up to 160 hours of training (Harrington, O'Meara, Collier, \& Schnelle, 2003). Aides in Taiwan are supposed to receive 100 hours of training and a certification exam, but not all aides receive minimum training and certificates (Sung, Chang, \& Tsai, 2005). In Mexico, aides receive "some on the job training" (Douglas, Meleis, Eribes, \& Kim, 1996). In Canada, the length of the care aide program varies from seven weeks in Ontario (personal support worker) to 32 weeks in the Northwest Territories (long term care attendant) (Health Employers Association of British Columbia, 2000). Canadian care aides are not regulated by provincial legislation and regulations seen for other members of the nursing team (LPNs, RPNs and RNs).

\section{Discussion}

Of the total articles (138), the frequency effect size was greatest for caring relationships and/or connectedness between aides and residents or aides and families, and collegial connections which appear to be very important motivational factors that may reduce turnover rates and increase quality of care (44.8\%). A number of nurse aides remain committed and motivated to remain on the job even though the working conditions appear to be deplorable. These aides are not motivated by solely by wages or the working environment but by a combination of intrinsic factors such as a belief that their job is important (Parsons et al. 2003) or a belief that they are needed (Monahan \& McCarthy, 1992).

This finding was followed closely by the concern regarding lack of financial compensation and rewards which shape general job dissatisfaction (frequency effect size 38.0\%), supervisory styles that are generally hierarchical, demeaning and dismissive (frequency effect size $37.3 \%$ ) and violence and aggression in the workplace which pose serious threats to the personal safety of the aide (frequency effect size 36.6\%). As a group, nurse aides have complained that they very little voice. They are rarely directly consulted about their opinions and experiences. They are marginalized by frequent episodes of assault and by feelings of degradation and humiliation resulting from bureaucracy. Poor working conditions lead to feelings of guilt because most genuinely care about the residents.

There is a cost to society for overlooking the work of nurse aides, portraying nurse aide work as unskilled or ignoring aides as valuable sources of information. As the population ages, the care aide role will become a pivotal issue. Aides serve a very vulnerable segment of our society therefore "some interest must be taken in (aides)...if the care provided to the elderly is truly a concern" (Atchison, 1998, p.137). 
Although care aides are most commonly utilized in residential continuing care they are also now being introduced to acute care settings. Job/role descriptions are continuously being updated and rewritten as part of the process of introducing the care aide to medical and surgical nursing units (nursing service aide). These are the same aides who report not feeling valued or nourished by their organizations. "I know I am dispensable" (quote from aide, Jervis, 2002a, p. 18). "It's like you're low class as a nursing assistant, you're on the bottom - which I don't like" (quote from aide, Jervis, 2002a, p.17).

Research about nurse aides is important because there are so many qualities of care issues and so many unsolved problems in their working environments. If organizations are concerned about positive outcomes for patients in acute and long term care and if they are concerned about improving the performance of individual workers and the organizations themselves, then they should address the needs voiced by the aides (Liu, 2006, p.56). Finally, heavy reliance on American research regarding the work as arduous, demanding and often demoralizing is a limitation. Further work is required to determine if American findings are truly generalizable to other countries.

\section{References}

Ahmed, L.B., \& Kitson, A. (1993). Complementary roles of nurse and health-care assistant. Journal of Clinical Nursing, 2, 287-297.

Anderson, R.A., Ammarell, N., Bailey, D., Clon-Emeric, C., Corazzini, K.N., Lillie, M., Piven, M.L., Utley-Smith, Q., \& McDaniel, R.R. (2005). Nurse assistant mental models, sensemaking, care actions, and consequences for nursing home residents. Qualitative Health Research, 15(8), 1006-1021.

Anderson, R.A., Bailey, D.E., Corazzini, K., \& Piven, M.L. (2005). The power of relationship for high-quality long term care. Journal of Nursing Care Quality, 20(2), 103-106

Anderson, R.A., Corazzini, K.N., \& McDaniel, R.R. (2004). Complexity science and the dynamics of climate and communication: Reducing nursing home turnover. The Gerontologist, 44(3), 378-388.

Atchison, J.H. (1998). Perceived job satisfaction factors of nursing assistants employed in Midwest nursing homes. Geriatric Nursing, 19(3), 135-138.

Banaszak-Holl, J., \& Hines, M.A. (1996). Factors associated with nursing home staff turnover. The Gerontologist, 36(4), 512-517. [Online] Available: http://login.ezproxy.library.ualberta.ca/login?url=http://proquest.umi.com.login.ezproxy.library.ualberta.ca/pqdweb?did $=10053652 \&$ sid $=2 \&$ Fmt $=6 \&$ clientId $=12301 \&$ RQT $=309 \&$ VName $=$ PQD

Banazak, D.A., Mickus, M., Averill, M., \& Colenda, C.C. (2000). Herding cats: Barriers to implementing a nurse aide educational program. Annals of Long Term Care, 8(10), 68-71.

Barney, J.L. (1983). A new perspective on nurse's aide training. Geriatric Nursing, 4(1), 44-48.

Barry, T., Brannon, D., \& Mor, V. (2005). Nurse aide empowerment strategies and staff stability: Effects on nursing home resident outcomes. The Gerontologist, 45(3), 309-317. [Online] Available: http://gerontologist.gerontologyjournals.org/cgi/reprint/45/3/309 (Retrieved June 13, 2008).

BC Ministry of Health (2007). Care aide competency project: Framework of practice for community health workers and resident care [Online] Available: http://www.llbc.leg.bc.ca/public/PubDocs/bcdocs/450048/CareAideCompetencyProjectFramework.pdf (Retrieved July 14, 2009).

Beck, C., Ortigara, A., Mercer, S., \& Shue, V. (1999). Enabling and empowering certified nursing assistants for dementia care. International Journal of Geriatric Psychiatry, 14(3), 197-212.

Berdes, C., \& Eckert, J.M. (2001). Race relations and caregiving relationships: A Qualitative examination of perspectives from residents and nurse's aides in three nursing homes. Research on Aging, 23(1), 109-126.

Bowers, B.J., \& Becker, M. (1992). Nurse's aides in nursing homes: The relationship between organization and quality. The Gerontologist, 32(3), 360-366.

Bowers, B.J., Esmond, S., \& Jacobson, N. (2000). The relationship between staffing and quality in long term care facilities: Exploring the views of nurse aides. Journal of Nursing Care Quarterly, 14(4), 55-64.

Bowers, B.J., Esmond, S., \& Jacobson, N. (2003). Turnover reinterpreted. CNAs talk about why they leave. Journal of Gerontological Nursing, 29(3), 36-43.

Brannon, D., Cohn, M.D., \& Smyer, M.A. (1990). Care giving as work: How nurse's aides rate it. Journal of Long Term Care Administration, 18, 10-14.

Brannon, D., Streit, A., \& Smyer, M.A. (1992). The psychosocial quality of nursing home work. Journal of Aging and Health, 4(3), 369-389. DOI: 10.1177/089826439200400303. 
Brannon, D., Zinn, J.S., Mor, V., \& Davis, J. (2002). An exploration of job, organizational, and environmental factors associated with high and low nursing assistant turnover. The Gerontologist, 42(2), 159-168. [Online] Available: http://proquest.umi.com.login.ezproxy.library.ualberta.ca/pqdlink?index $=5 \& \mathrm{did}=113196608 \& \mathrm{SrchMode}=3 \& \mathrm{sid}=6 \& \mathrm{~F}$ $\mathrm{mt}=6 \&$ VInst $=$ PROD\&VType $=$ PQD\&RQT=309\&VName=PQD\&TS=1214689527\&clientId=12301\&aid=1 (Retrieved June 28, 2008).

Brodaty, H., Draper, B., \& Low, L.F. (2003). Nursing home staff attitudes towards residents with dementia: Strain and satisfaction with work. Journal of Advanced Nursing, 44(6), 583-590.

Broughton, W., \& Golden, M.A. (1995). A profile of Pennsylvania nurse's aides. Geriatric Nursing, 16(3), $117-120$.

Burgio, L.D., Engel, G.T., Hawkins, A., McCormick, K, \& Scheve, A. (1990). A descriptive analysis of nursing behaviors in a teaching nursing home: Differences among NAs, LPNs, and RNs. The Gerontologist, 30, $107-112$.

Burgio, L.D., Jones, L.T., Butler, F., \& Engel, B.T. (1988). Behavior problems in an urban nursing home. Journal of Gerontological Nursing, 14(1), 31-34.

Canadian Nurses Association (CNA): Pan-Canadian Planning Committee on Unregulated Workers. (2008). Working with unregulated health workers: A discussion paper. [Online] Available: http://www.cna-nurses.ca/CNA/documents/pdf/publications/UHW_Valuing_2008_e.pdf(Retrieved April 25, 2009)

Castle, N.G. (2007). Assessing job satisfaction of nurse aides in nursing homes: The nursing home nurse aide job satisfaction questionnaire. Journal of Gerontological Nursing, 33(5), 41-47. [Online] Available: http://login.ezproxy.library.ualberta.ca/login?url=http://search.ebscohost.com/login.aspx?direct=true \&db=rzh\&AN=200 $9579905 \&$ loginpage $=$ Login. asp \&site $=$ ehost-live\&scope $=$ site.

Castle, N.G., Engberg, J., Anderson, R., \& Men, A. (2007). Job satisfaction of nurse aides in nursing homes: Intent to leave and turnover. The Gerontologist, 47(2), 193-2004.

Caudill, M., \& Patrick, M. (1989). Nursing assistant turnover in nursing homes and need satisfaction. Journal of Gerontological Nursing, 15(6), 24-30.

Chappell, N.L., \& Novak, M. (1992). The role of support in alleviating stress among nursing assistants. The Gerontologist, 32(3), 351-359. [Online] Available: http://login.ezproxy.library.ualberta.ca/login?url=http://proquest.umi.com.login.ezproxy.library.ualberta.ca/pqdweb?did $=1649200 \&$ sid $=8 \& \mathrm{Fmt}=6 \&$ clientId=12301\&RQT=309\&VName=PQD (Retrieved June 28, 2008).

Chappell, N.L., \& Novak, M. (1994). Caring for institutionalized elders: Stress among nursing assistants. The Journal of Applied Gerontology, 13(3), 299-315.

Cotton, J.L., \& Tuttle, J.M. (1986). Employee turnover: A meta-analysis and review with implications for research. Academy of Management Review, 11(1), 55-70. [Online] Available: http://login.ezproxy.library.ualberta.ca/login?url=http://search.ebscohost.com/login.aspx?direct=true $\& d b=b t h \& A N=428$ 2625\&loginpage $=$ Login. asp\&site $=$ ehost-live\&scope $=$ site

Dewar, B.J., \& McCleod-Clark, J. (1992). The role of the paid non professional nursing helper: A review of the literature. Journal of Advanced Nursing, 17(1), 113-120.

Dougherty, L., Bolger, J., Preston, D., Jones, S., \& Payne, S. (1992). Effects of exposure to aggressive behaviour on job satisfaction of health care staff. The Journal of Applied Gerontology, 11(2), 160-172.

Douglas, M.K., Meleis, A.I., Eribes, C., \& Kim, S. (1996). The work of auxiliary nurses in Mexico: stressors, satisfiers and coping strategies. International Journal of Nursing Studies, 33(5), 495-505.

Eaton, S.C. (2000). Beyond 'unloving care': Linking human resource management and patient care quality in nursing homes. International Journal of Human Resource Management, 11(3), 591-616. [Online] Available: http://login.ezproxy.library.ualberta.ca/login?url=http://search.ebscohost.com/login.aspx?direct=true \&db=bth\&AN=421 9996\&loginpage $=$ Login. asp\&site $=$ ehost-live\&scope $=$ site

Evers, W., Tomic, W., \& Brouwers, A. (2002). Aggressive behaviour and burnout among staff of homes for the elderly. International Journal of Mental Health Nursing, 11, 2-9.

Feldt, K.S., \& Ryden, M.B. (1992). Aggressive behaviour. Educating nursing assistants. Journal of Gerontological Nursing, 18(5), 3-12.

Fitzwater, E., \& Gates, D. (2002). Testing an intervention to reduce assaults on nursing assistants in nursing homes: A pilot study. Geriatric Nursing, 23(1), 18-23.

Foner, N. (1994). Nursing home aides: Saints or monsters? The Gerontologist, 34(2), 245-250. 
Freyne, A., \& Wrigley, M. (1996). Aggressive incidents towards staff by elderly patients with dementia in a long-stay ward. International Journal of Geriatric Psychiatry, 11(1), 57-63. [Online] Available: http://search.ebscohost.com/login.aspx?direct=true\&db=a9h\&AN=14149537\&site=ehost-live

Friedman, S.M., Daub, C., Cresci, K., \& Keiser, R. (1999). A comparison of job satisfaction among nursing assistants in nursing homes and the program of all-inclusive care for the elderly. The Gerontologist, 39(4), 434-439.

Garland, T.N., Oyabu, N., \& Gipson, G.A. (1988). Stayers and leavers: A comparison of nurse assistants employed in nursing homes. Journal of Long Term Care Administration, 16, 23-9.

Garland, T.N., Oyabu, N., \& Gipson, G.A. (1989). Job satisfaction among nurse assistants employed in nursing homes: An analysis of selected job characteristics.Journal of Aging Studies, 3, 369-383.

Gates, D.M., Fitzwater, E., \& Succop, P. (2003). Relationships of stressors, strain, and anger to caregiver assaults. Issues in Mental Health Nursing, 24(8), 775-793.

Grant, L.A., Kane, R.A., Potthoff, S.J., \& Ryden, M. (1996). Staff training and turnover in Alzheimer special care units: Comparisons with non-special care units. Geriatric Nursing, 17(6), 278-282.

Grau, L., \& Wellin, E. (1992). The organizational cultures of nursing homes: Influences on responses to external regulation controls. Qualitative Health Research, 12(1), 15-23. DOI: 10.1177/104973239200200104.

Grau, L., Chandler, B., Burton, B., \& Kolditz, D. (1991). Institutional loyalty and job satisfaction among nurse aides in nursing homes. Journal of Aging and Health, 3(1), 47-65.

Greenhalgh, T., Robert, G., Macfarlane, F., Bate, P., Kyriakidou, O., \& Peacock, R. (2005). Storylines of research in diffusion of innovation: A meta-narrative approach to systematic review. Social Science and Medicine, 61, 417-430. DOI: $10.1016 /$ j.socscimed.2004.12.001

Grieshaber, L.D., Parker, P., \& Deering, J. (1995). Job satisfaction of nursing assistants in long-term care. Health Care Supervisor, 13, 18-28.

Harrington, C., \& Swan, J.H. (2003). Nursing home staffing, turnover, and case mix. Medical Care Research and Review, 60(3), 366-392. [Online] Available: http://ft.csa.com.login.ezproxy.library.ualberta.ca/ids70/resolver.php?sessid=c4v6j8c019164ln8bbpv0mvof7\&server=w wwmi9.csa.com\&check=98d6e7fbb19ef28977fb4d7a3a2b0f35\&db=sagenurs-setc\&key=10775587\%2F10.1177_10775 $58703254692 \&$ mode $=$ pdf

Harrington, C., O’Meara, J., Collier, E., \& Schnelle, J.F. (2003). Nursing indicators of quality in nursing homes. A web-based approach. Journal of Gerontological Nursing, 29(10), 5-11. [Online] Available: http://web.ebscohost.com.login.ezproxy.library.ualberta.ca/ehost/pdf?vid=3\&hid=22\&sid=2418cae4-a19a-4837-b662-c 23c9b019477\%40sessionmgr2

Helmer, F.T., Olson, S.F., \& Heim, R.I. (1993). Strategies for nurse aide job satisfaction. The Journal of Long Term Care Administration, 21(2), 10-14.

Hospital Employees Union Facilities Subsector Wage Schedule retrieved November 23, 2007 from http://www.heu.org/\%7EDOCUMENTS/facwages2006-2010.pdf

Hsieh, P., \& Su, H. (2007). Retention and attrition of certified care assistants in the long-term care industry from the Taipei area: An interview survey. International Journal of Nursing Studies, 44(1), 93-104. [Online] Available: http://www.sciencedirect.com/science?_ob=PublicationURL\&_tockey=\%23TOC\%235067\%232007\%23999559998\%2 $3639562 \% 23$ FLA $\% 23 \&$ cdi $=5067 \& \_$pubType $=J \& \_$auth $=$y\&_acct $=$C000050484\&_version $=1$ \&_urlVersion $=0 \&$ useri $\mathrm{d}=1022551 \& \mathrm{md} 5=\mathrm{b} 025 \mathrm{fe} 00180 \mathrm{~b} 96 \mathrm{e} 9 \mathrm{f} 3 \mathrm{c} 5010 \mathrm{f0f} 9542 \mathrm{~cd}$

Jervis, L.L. (2002a). Working in and around the 'chain of command': Power relations among nursing staff in an urban nursing home. Nursing Inquiry, 9(1), 12-23.

Jervis, L.L. (2002b). Contending with problem behaviors in the nursing home. Archives of Psychiatric Nursing, 16(1), 32-38.

Kovach, C.R., \& Krejci, J.W. (1998). Facilitating change in dementia care. The Journal of Nursing Administration, 28, $17-27$.

Kristiansen, L., Hellzen, O., \& Asplund, K. (2006). Swedish assistant nurses'experiences of job satisfaction when caring for persons suffering from dementia and behavioural disturbances. An interview study. International Journal of Qualitative Studies on Health and Well-being, 1, 245-256.

Lin, S.M., Yin, T.J., \& Li, I.C. (2002). An exploration of work stressors and correlators for nurse's aides in long term care facilities. The Journal of Nursing Research, 10(3), 177-186. 
Liu, L. (2006). Job satisfaction of certified nursing assistants and its influence on the general satisfaction of nursing home residents: An exploratory study in southern Taiwan. Geriatric Nursing, 28(1), 54-62.

Manthey, M. (1989). Practice partnerships: The newest concept in care delivery. Journal of Nursing Administration, 19(2), 33-35.

Manton, K.G. (1988). A longitudinal study of functional change and mortality in the United States. Journal of Gerontology, 43, S153-S161.

Mercer, S.O., Heacock, P., \& Beck, C. (1993). Nurse's aides in nursing homes: Perceptions of training, work loads, racism, and abuse issues. Journal of Gerontological Social Work, 21, 95-112.

Mercer, S.O., Heacock, P., \& Beck, C. (1994). Nurse's aides in nursing homes: a study of caregivers. Journal of Women and Aging, 6, 107-121.

Monahan, R.S., \& McCarthy, S. (1992). Nursing home employment: The nurse's aide perspective. Journal of Gerontological Nursing, 18(2), 13-16.

Moyle, W., Skinner, J., Rowe, G., \& Gork, C. (2003). Views of job satisfaction and dissatisfaction in Australian long term care. Journal of Clinical Nursing, 12(2), 168-176. [Online] Available: http://login.ezproxy.library.ualberta.ca/login?url=http://search.ebscohost.com/login.aspx?direct=true \&db=a9h\&AN=91 90654\&loginpage $=$ Login. asp\&site $=$ ehost-live \&scope $=$ site

Parsons, S.K., Simmons, W.P., Penn, K., \& Furlough, M. (2003). Determinants of satisfaction and turnover among nursing assistants. Journal of Gerontological Nursing, 29(3), 51-58.

Patchner, M.A., \& Patchner, L.S. (1993). Essential staffing for improved nursing home care: The permanent assignment model. Nursing Homes, 43, 37-39.

Ramirez, M., Teresi, J., \& Holmes, D. (2006). Demoralization and attitudes toward residents among certified nurse assistants in relation to job stressors and work resources: Cultural diversity in long term care. Journal of Cultural Diversity, 13(2), 119-125.

Riggs, C.J., \& Rantz, M.J. (2001). A model of staff support to improve retention in long term care. Nursing Adminstration Quarterly, 25(2), 43-54.

Sandelowski, M., Barroso, J., \& Voils, C.I. (2007). Using Qualitative metasummary to synthesize Qualitative and Quantitative descriptive findings. Research in Nursing and Health, 30, 99-111.

Secrest, J., Iorio, D.H., \& Martz, W. (2005). The meaning of work for nursing assistants who stay in long term care. Journal of Clinical Nursing, 14(8b), 90-97. [Online] Available: http://web.ebscohost.com.login.ezproxy.library.ualberta.ca/ehost/pdf?vid=3\&hid=4\&sid=cb0206cf-fc0c-48fd-815a-e2c a63595c $7 \mathrm{~b} \% 40$ sessionmgr7

Statistics Canada (2002). Report on the demographic situation in Canada (released September, 2006). Ottawa: Statistics Canada; Catalogue no. 91-209-XIE. [Online] Available: http://cansim2.statcan.ca/cgiwin/cnsmcgi.pgm?Lang=E\&SP_Action=Result\&SP_ID=3869\&SP_TYP=5\&SP_Sort=1 (Retrieved November 7, 2007).

Sung, H., Chang, S., \& Tsai, C. (2005). Working in long-term care settings for older people with dementia: Nurse's aides. Journal of Clinical Nursing, 14, 587-593.

Tellis-Nayak, V., \& Tellis-Nayak, M. (1989). Quality of care and the burden of two cultures: When the world of the nurse's aide enters the world of the nursing home. The Gerontologist, 29, 307-313.

Teresi, J., Holmes, D., Ramires, M., \& Kong, J. (1998). Staffing patterns, staff support and training in special care and non special care units. Journal of Mental Health and Aging, 4(4), 443-458.

Whittemore, R., \& Knafl, K. (2005). The integrative review: Updated methodology. Journal of Advanced Nursing, 52(5), 546-553.

Work Futures BC (2005). NOC 3413 Occupational Outlooks. [Online] Available: http://www.workfutures.bc.ca/profiles/profile.cfm?noc=3413\&lang=en\&site=graphic (Retrieved May 22, 2008). 
Table 1. The Full Contribution of the Different Sources to the Final Metasummary

\begin{tabular}{|c|c|c|c|c|}
\hline $\begin{array}{l}\text { Author(s) } \\
\text { Year } \\
\text { Country }\end{array}$ & $\begin{array}{l}\text { Study } \\
\text { Design }\end{array}$ & Subjects & Method & Results \\
\hline $\begin{array}{l}\text { Advisory } \\
\text { Committee on } \\
\text { Health Human } \\
\text { Resources } \\
2000 \\
\text { Canada }\end{array}$ & $\begin{array}{l}\text { Government } \\
\text { sponsored } \\
\text { report } \\
\text { addressing } \\
\text { nurse } \\
\text { shortage in } \\
\text { Canada }\end{array}$ & & & $\begin{array}{l}\text { National absence of data about nurse aides } \\
\text { Nurse aides are non-regulated } \\
\text { Nurse aides are not defined as nurses } \\
\text { Basic policy questions are unanswerable because of } \\
\text { the absence of a national data bank. In comparison } \\
\text { to national data banks available to US investigators }\end{array}$ \\
\hline $\begin{array}{c}\text { Ahmed, \& } \\
\text { Kitson } \\
1993 \\
\text { England }\end{array}$ & Qualitative & $\begin{array}{l}2 \text { community } \\
\text { hospitals and } 2 \\
\text { units for people } \\
\text { with learning } \\
\text { disabilities } \\
\text { Mixed staff } \\
\mathrm{N}=48\end{array}$ & $\begin{array}{l}\text { "a multi-method } \\
\text { approach" } \\
\text { Semi-structured } \\
\text { interviews, } \\
\text { Informal opinions, } \\
\text { non-participant } \\
\text { observation, field } \\
\text { notes }\end{array}$ & $\begin{array}{l}\text { To provide quality care, effective leadership and } \\
\text { efficient teams rather than primary nursing are } \\
\text { needed }\end{array}$ \\
\hline $\begin{array}{l}\text { Anderson, } \\
\text { Ammarell, } \\
\text { Bailey, } \\
\text { Clon-Emeric, } \\
\text { Corazzini, } \\
\text { Lillie, Piven... } \\
2005 \\
\text { USA }\end{array}$ & Qualitative & $\begin{array}{l}11 \text { nurse aides } \\
\text { and } 89 \text { "other" } \\
\text { staff members }\end{array}$ & $\begin{array}{l}\text { Observation and } \\
\text { interview data }\end{array}$ & $\begin{array}{l}\text { "Mother wit" guides aides who treat residents as } \\
\text { their own children = infantilization and } \\
\text { misinterpretations of depression and pain. The } \\
\text { Golden rule: respond to residents as you would want } \\
\text { someone to respond to you. Aides act without the } \\
\text { benefit of professional interpretations. Aides possess } \\
\text { raw data that can be interpreted by RNs. Aides } \\
\text { should be involved in care planning. }\end{array}$ \\
\hline $\begin{array}{l}\text { Anderson, } \\
\text { Bailey, } \\
\text { Corazzini, \& } \\
\text { Piven } \\
2005 \\
\text { USA }\end{array}$ & Opinion & & & $\begin{array}{l}\text { What contributes to poor quality of care? RNs who } \\
\text { have minimal interaction with aides, LPNs who have } \\
\text { minimal interaction with aides, aides in small } \\
\text { cliques, no rewards for team work, heavy reliance on } \\
\text { rules and rule enforcement, managers who have } \\
\text { inadequate information and managers who fail to } \\
\text { acknowledge good behaviour }\end{array}$ \\
\hline $\begin{array}{l}\text { Anderson, } \\
\text { Corazzini, \& } \\
\text { McDaniel } \\
2004 \\
\text { USA }\end{array}$ & Quantitative & $\begin{array}{l}2317 \text { aides in } \\
164 \text { nursing } \\
\text { homes in Texas }\end{array}$ & survey & $\begin{array}{l}\text { Lower turnover is dependent on interaction climate } \\
\text { and communication. Reward based climates, } \\
\text { communication openness and accuracy = lower } \\
\text { turnover rates. }\end{array}$ \\
\hline
\end{tabular}




\begin{tabular}{|c|c|c|c|c|}
\hline $\begin{array}{l}\text { Anderson, } \\
\text { Issel, \& } \\
\text { McDaniel } \\
2003 \\
\text { USA }\end{array}$ & Quantitative & $\begin{array}{l}\text { DONS and } \\
\text { RNs in } 164 \\
\text { Texas nursing } \\
\text { homes }\end{array}$ & $\begin{array}{l}\text { Surveys given to } \\
\text { DON and RNs } \\
\text { regarding NA } \\
\text { patterns of behaviour }\end{array}$ & $\begin{array}{l}\text { Relationship oriented leadership and less } \\
\text { formalization resulted in decreased use of restraints, } \\
\text { decreased incidence of fractures }\end{array}$ \\
\hline $\begin{array}{c}\text { Astrom, } \\
\text { Nilsson, } \\
\text { Norberg, } \\
\text { Sandman, \& } \\
\text { Winblad } \\
1991 \\
\text { Sweden }\end{array}$ & Quantitative & $\begin{array}{l}\text { RNs, LPNs, } \\
\text { NAs in one } \\
\text { somatic long } \\
\text { term care clinic } \\
\text { and one } \\
\text { psycho- } \\
\text { geriatric clinic } \\
\mathrm{n}=358\end{array}$ & $\begin{array}{l}\text { Empathy scale, } \\
\text { burnout measure }\end{array}$ & $\begin{array}{l}\text { Staff with highest empathy rated close contact with } \\
\text { patients as most important. Staff with lowest } \\
\text { empathy rated improvement in patients' health and } \\
\text { contact with colleagues as most important. Those } \\
\text { who have less positive outcomes in work risk more } \\
\text { burnout. }\end{array}$ \\
\hline $\begin{array}{l}\text { Atchison } \\
1998 \\
\text { USA }\end{array}$ & Quantitative & $\begin{array}{l}\text { Nurse aides } \\
\mathrm{N}=283 \text { in } 24 \\
\text { nursing homes }\end{array}$ & $\begin{array}{l}\text { Questionnaire } \\
5 \text { point Likert scale }\end{array}$ & $\begin{array}{l}\text { Socialization at work is an important factor for job } \\
\text { satisfaction }\end{array}$ \\
\hline $\begin{array}{c}\text { Baldwin, } \\
\text { Roberts, } \\
\text { Fitzpatrick, } \\
\text { While, \& } \\
\text { Cowan } \\
2003 \\
\text { British }\end{array}$ & $\begin{array}{l}\text { Review of } \\
\text { existing } \\
\text { literature }\end{array}$ & & & $\begin{array}{l}\text { Lack of role clarification of roles: support workers } \\
\text { saw their work as similar to RNs. RNs saw support } \\
\text { workers' roles as basic care }\end{array}$ \\
\hline $\begin{array}{l}\text { Banazak, } \\
\text { Mickus, } \\
\text { Averill, \& } \\
\text { Colenda } \\
2000 \\
\text { USA }\end{array}$ & $\begin{array}{l}\text { Review of } \\
\text { lessons } \\
\text { learned in } \\
\text { implementing } \\
\text { an education } \\
\text { intervention }\end{array}$ & $\begin{array}{l}92 \text { nurse aides, } \\
35 \% \\
\text { attendance rate }\end{array}$ & & $\begin{array}{l}\text { Actual staff attendance at the in-service training was } \\
\text { marginal due to lack of time and requirement to } \\
\text { forgo patient care in order to attend. }\end{array}$ \\
\hline $\begin{array}{l}\text { Banaszak-Holl } \\
\text { \& Hines } \\
1996 \\
\text { USA }\end{array}$ & Quantitative & $\begin{array}{l}254 \text { nursing } \\
\text { homes in } 10 \\
\text { states }\end{array}$ & $\begin{array}{l}\text { Telephone survey of } \\
\text { DONs and } \\
\text { administrators plus } \\
\text { access data bank } \\
\text { (RAI) }\end{array}$ & $\begin{array}{l}\text { Involvement of aides in care planning can } \\
\text { significantly reduce turnover. Intensity of work } \\
\text { demands does not result in increased turnover. } \\
\text { Training for aides does not reduce turnover }\end{array}$ \\
\hline $\begin{array}{c}\text { Barney } \\
1983 \\
\text { USA }\end{array}$ & Opinion & & $\begin{array}{l}\text { Author spent two } \\
\text { days doing the work } \\
\text { of a nurse aide }\end{array}$ & $\begin{array}{l}\text { Aides are well motivated. Supervision is limited. } \\
\text { Author concludes best care given in a home with a } \\
\text { family or social quality. Community involvement is } \\
\text { important. Cultural homogeneity contributes to } \\
\text { better care }\end{array}$ \\
\hline $\begin{array}{l}\text { Barry, } \\
\text { Brannon, \& } \\
\text { Mor }\end{array}$ & Quantitative & $\begin{array}{l}\text { Directors of } \\
\text { nursing } n=156 \text {, } \\
\text { day shift }\end{array}$ & survey & $\begin{array}{l}\text { Higher number of rewards given to nurse aides } \\
\text { resulted in lower incidence of pressure ulcers. Nurse } \\
\text { aides who had more influence resulted in higher }\end{array}$ \\
\hline
\end{tabular}




\begin{tabular}{|c|c|c|c|c|}
\hline $\begin{array}{l}2005 \\
\text { USA }\end{array}$ & & $\begin{array}{l}\text { charge nurses } \\
\mathrm{n}=430 \\
\text { In } 156 \text { facilities }\end{array}$ & & social engagement for residents \\
\hline $\begin{array}{l}\text { Beck, } \\
\text { Baldwin, } \\
\text { Modlin, \& } \\
\text { Lewis } \\
1990 \\
\text { USA }\end{array}$ & Quantitative & $\begin{array}{l}21 \mathrm{RNs} \\
20 \text { aides }\end{array}$ & Guided interview & $\begin{array}{l}\text { Information on characteristics \& management of } \\
\text { aggressive behaviour. Aggression occurs more often } \\
\text { in the morning, during dressing. Soothing, using } \\
\text { comfort measures and reasoning were commonly } \\
\text { used by aides to reduce aggression. }\end{array}$ \\
\hline $\begin{array}{l}\text { Beck, Doan, } \\
\text { \& Cody } \\
2002 \\
\text { USA }\end{array}$ & $\begin{array}{l}\text { Opinion/disc } \\
\text { ussion }\end{array}$ & & & $\begin{array}{l}\text { Aides provide } 8 \text { of } 10 \text { hours of paid care. Discussion } \\
\text { of challenges (specifically } \\
\text { organizational... hierarchical structures) }\end{array}$ \\
\hline $\begin{array}{l}\text { Beck, } \\
\text { Ortigara, } \\
\text { Mercer, \& } \\
\text { Shue } \\
1999 \\
\text { USA }\end{array}$ & $\begin{array}{l}\text { Literature } \\
\text { Review }\end{array}$ & & & $\begin{array}{l}\text { Most nursing homes organized hierarchically, aides } \\
\text { receive few rewards for performance, aides have few } \\
\text { opportunities to feel successful, aides minimally } \\
\text { involved in care planning, aides are mostly African } \\
\text { American or Hispanic and supervisors are mostly } \\
\text { White, residents are primarily White. }\end{array}$ \\
\hline $\begin{array}{l}\text { Berdes \& } \\
\text { Eckert } \\
2001 \\
\text { USA }\end{array}$ & Qualitative & $\begin{array}{l}10 \text { residents } \\
\text { and } 10 \text { aides in } \\
\text { three homes ( } \mathrm{n} \\
=60 \text { ) }\end{array}$ & $\begin{array}{l}\text { Face to face } \\
\text { interviews }\end{array}$ & $\begin{array}{l}75 \% \text { of aides experience racism on the job. Job } \\
\text { characterized by low wages, few or no benefits, low } \\
\text { opportunity for advancement, job instability, } \\
\text { over-representation of minorities }\end{array}$ \\
\hline $\begin{array}{c}\text { Borson, } \\
\text { Reichman, } \\
\text { Coyne, } \\
\text { Rovner, \& } \\
\text { Sakauye } \\
2000 \\
\text { USA }\end{array}$ & Quantitative & $\begin{array}{l}\text { Nursing } \\
\text { directors of } \\
\text { medicare } \\
\text { certified } \\
\text { facilities } \\
\mathrm{N}=899\end{array}$ & survey & $\begin{array}{l}\text { Nursing directors felt that only } 32 \% \text { of nurse aides } \\
\text { possessed expertise in managing residents" } \\
\text { "disruptive behaviours" }\end{array}$ \\
\hline $\begin{array}{c}\text { Bowers } \\
1989 \\
\text { British }\end{array}$ & Opinion & & & $\begin{array}{l}\text { Primary nursing has some serious repercussions: } \\
\text { over-involvement, disagreements about care } \\
\text { strategies, divisions in nursing team, lack of } \\
\text { communication, weakening of the team as a whole }\end{array}$ \\
\hline $\begin{array}{c}\text { Bowers, \& } \\
\text { Becker } \\
1992 \\
\text { USA }\end{array}$ & Qualitative & $\begin{array}{l}\text { Nurse aides in } \\
3 \text { urban nursing } \\
\text { homes } \\
\mathrm{N}=30\end{array}$ & $\begin{array}{l}\text { Participant } \\
\text { observation, in-depth } \\
\text { interviews, grounded } \\
\text { theory }\end{array}$ & $\begin{array}{l}\text { Each nurse aide develops his or her own working } \\
\text { strategy in order to survive by cutting corners and } \\
\text { breaking rules }\end{array}$ \\
\hline $\begin{array}{l}\text { Bowers, } \\
\text { Esmond \& } \\
\text { Jacobson } \\
2000\end{array}$ & Qualitative & $\begin{array}{l}\text { Nurse aides } \\
\mathrm{n}=38\end{array}$ & $\begin{array}{l}\text { Participant } \\
\text { observation and } \\
\text { in-depth } \\
\text { interviewing }\end{array}$ & $\begin{array}{l}\text { Relationships between nurse aides and residents are } \\
\text { an essential determinant of quality of care. Adequate } \\
\text { staffing is essential to allow NAs to nurture } \\
\text { relationships with residents. }\end{array}$ \\
\hline
\end{tabular}




\begin{tabular}{|c|c|c|c|c|}
\hline USA & & & $\begin{array}{l}\text { Grounded theory, } \\
\text { constant comparative }\end{array}$ & \\
\hline $\begin{array}{l}\text { Bowers, } \\
\text { Esmond \& } \\
\text { Jacobson } \\
2003 \\
\text { USA }\end{array}$ & Qualitative & $\begin{array}{l}\text { Nurse aides, } \mathrm{n} \\
=41\end{array}$ & $\begin{array}{l}\text { Grounded theory } \\
\text { dimensional analysis }\end{array}$ & $\begin{array}{l}\text { Aides do not necessarily quit because of hard work } \\
\text { or poor pay. Rather, it is the way aides are treated by } \\
\text { their employers that accounts for their leaving. } \\
\text { Dismissing experiences will override positive } \\
\text { experiences. Managers must develop a culture of } \\
\text { respect, instead of demeaning or humiliating aides. }\end{array}$ \\
\hline $\begin{array}{c}\text { Brannon, } \\
\text { Cohn, \& } \\
\text { Smyer } \\
1990 \\
\text { USA }\end{array}$ & Quantitative & 388 aides & $\begin{array}{l}\text { Employee survey of } \\
21 \text { Pennsylvania } \\
\text { nursing homes }\end{array}$ & $\begin{array}{l}\text { When compared with women in small organizations: } \\
\text { aides less satisfied with pay, less satisfied with skill } \\
\text { variety, more satisfied with co-workers, more } \\
\text { satisfied with task significance }\end{array}$ \\
\hline $\begin{array}{c}\text { Brannon, } \\
\text { Smyer, Cohn, } \\
\text { Borchardt, } \\
\text { Landry, Jay et } \\
\text { al. } \\
1988 \\
\text { USA }\end{array}$ & Quantitative & $\begin{array}{l}388 \text { aides and } \\
101 \text { LPNs in } 46 \\
\text { nursing homes } \\
\text { in } \\
\text { Pennsylvania }\end{array}$ & $\begin{array}{l}\text { Job diagnostic } \\
\text { survey }\end{array}$ & $\begin{array}{l}\text { Aide positions have less motivating potential than } \\
\text { LPN positions, aides receive inadequate feedback, } \\
\text { routines and hierarchies result in self limiting } \\
\text { contracts that inhibit motivation. Wage structure } \\
\text { plagues staff recruitment and retention. }\end{array}$ \\
\hline $\begin{array}{c}\text { Brannon, } \\
\text { Streit, \& } \\
\text { Smyer } \\
1992 \\
\text { USA }\end{array}$ & Quantitative & $\begin{array}{l}\text { Observation of } \\
214 \text { aides in } 4 \\
\text { nursing homes }\end{array}$ & $\begin{array}{l}\text { Functional job } \\
\text { analysis technique of } \\
3371 \text { tasks }\end{array}$ & $\begin{array}{l}\text { Orientation of tasks is not predominantly toward the } \\
\text { residents. Complexity of tasks is low. } \\
\text { Tasks with greatest psychosocial quality are } \\
\text { performed less frequently }\end{array}$ \\
\hline $\begin{array}{l}\text { Brannon, } \\
\text { Zinn, Mor, \& } \\
\text { Davis } \\
2002 \\
\text { USA }\end{array}$ & Quantitative & $\begin{array}{l}308 \text { nursing } \\
\text { facilities in } 8 \\
\text { states. } 288 \\
\text { DONs }\end{array}$ & Telephone survey & $\begin{array}{l}\text { Predictors of low turnover: untrained supervisors, } \\
\text { low RN turnover, flat management structure, } \\
\text { presence of a union. Very low turnover rates are } \\
\text { undesirable. Predictors of high turnover: high RN } \\
\text { turnover, training site, investor owned facility rather } \\
\text { than non-profit }\end{array}$ \\
\hline $\begin{array}{l}\text { Brodaty, } \\
\text { Draper \& Low } \\
2003 \\
\text { Australia }\end{array}$ & Quantitative & $\begin{array}{l}253 \text { staff in } 12 \\
\text { nursing homes: } \\
\text { no } \\
\text { differentiation } \\
\text { between types } \\
\text { of "staff" }\end{array}$ & Questionnaire survey & $\begin{array}{l}91 \% \text { of "staff" reported that they were happy in their } \\
\text { job. } 25 \% \text { reported that the residents provided no job } \\
\text { satisfaction }\end{array}$ \\
\hline $\begin{array}{l}\text { Broughton \& } \\
\text { Golden } \\
1995 \\
\text { USA }\end{array}$ & Quantitative & $\begin{array}{l}\text { Random } \\
\text { samples from } \\
38 \text { nursing } \\
\text { homes }\end{array}$ & Telephone interview & $\begin{array}{l}83 \% \text { would value more training about managing } \\
\text { behaviours of Alzheimer's disease. } 90 \% \text { interested } \\
\text { in further training regarding dementias. } 89 \% \text { value a } \\
\text { support group. Suggest acknowledge the }\end{array}$ \\
\hline
\end{tabular}




\begin{tabular}{|c|c|c|c|c|}
\hline & & Aides $=273$ & & $\begin{array}{l}\text { contributions of aides, include aides in care } \\
\text { planning, provide support groups }\end{array}$ \\
\hline $\begin{array}{l}\text { Burgio, Engel, } \\
\text { Hawkins, } \\
\text { McCormick, } \\
\text { \& Scheve } \\
1990 \\
\text { USA }\end{array}$ & Quantitative & $\begin{array}{l}\text { Sampling of } \\
\text { aide behaviours } \\
\text { in one } 223 \text { bed } \\
\text { nursing home, } \\
7 \text { times a day } \\
\text { for } 37 \text { months }\end{array}$ & & $\begin{array}{l}\text { Covert sampling. Research done under the guise of } \\
\text { incontinence research. Aides did not give consent to } \\
\text { being observed. Most observations occurred in the } \\
\text { hallways. LPNs were observed to be engaged in } \\
\text { more direct care activities than aides (in the } \\
\text { hallways). }\end{array}$ \\
\hline $\begin{array}{l}\text { Burgio, } \\
\text { Fisher, } \\
\text { Fairchild, } \\
\text { Scilley, \& } \\
\text { Hardin } \\
2004 \\
\text { USA }\end{array}$ & $\begin{array}{l}\text { Between } \\
\text { groups } \\
\text { quasi-experi } \\
\text { mental } \\
\text { comparison } \\
\text { design }\end{array}$ & $\begin{array}{l}4 \text { nursing } \\
\text { homes in } \\
\text { Alabama }\end{array}$ & $\begin{array}{l}\text { Observations plus } \\
\text { multiple tools to } \\
\text { examine permanent } \\
\text { versus rotating } \\
\text { assignment }\end{array}$ & $\begin{array}{l}\text { Two facilities permanent assignment versus two } \\
\text { facilities rotating assignment: residents received } \\
\text { higher hygiene rating in permanent assign. But } \\
\text { residents received more meds, more psychotropic } \\
\text { meds in permanent assign. No differences in } \\
\text { disruptive behaviours, no differences in turnover } \\
\text { rates, more absenteeism in permanent assignment }\end{array}$ \\
\hline $\begin{array}{l}\text { Burgio, } \\
\text { Tice-Jones, } \\
\text { Butler, \& } \\
\text { Engel } \\
1988 \\
\text { USA }\end{array}$ & Quantitative & $\begin{array}{l}32 \text { geriatric } \\
\text { assistants in } \\
\text { one nursing } \\
\text { home }\end{array}$ & survey & $\begin{array}{l}22 \% \text { of residents are verbally abusive, } 20 \% \text { are } \\
\text { physically abusive towards geriatric assistants }\end{array}$ \\
\hline $\begin{array}{l}\text { Caris-Verhalle } \\
\text { n, Kerstra, \& } \\
\text { Bensing } \\
1997 \\
\text { Netherlands }\end{array}$ & $\begin{array}{l}\text { Literature } \\
\text { review of } \\
\text { research } \\
\text { about } \\
\text { communicati } \\
\text { on with } \\
\text { residents }\end{array}$ & & & $\begin{array}{l}\text { Interaction with residents is low, speakers modify } \\
\text { speech (baby talk), interaction styles are largely } \\
\text { superficial, monotonous or routinized. Time } \\
\text { pressure results in brief, task related interactions. }\end{array}$ \\
\hline $\begin{array}{l}\text { Carpiac-Clave } \\
\text { r \& } \\
\text { Levy-Storms } \\
2007 \\
\text { USA }\end{array}$ & Qualitative & $\begin{array}{l}\text { Video analysis } \\
\text { of } 23 \text { aides } \\
\text { interactions } \\
\text { with residents }\end{array}$ & Grounded theory & $\begin{array}{l}\text { Video recording of mealtimes and analysis of } \\
\text { interactions. } \\
\text { Communication between aides and residents is } \\
\text { limited, lacks depth and residents not generally } \\
\text { given enough time to respond. }\end{array}$ \\
\hline $\begin{array}{l}\text { Castle } \\
2007 \\
\text { USA }\end{array}$ & Quantitative & $\begin{array}{l}72 \text { nursing } \\
\text { homes in } 6 \\
\text { states } \\
\text { Nurse aides } \\
\mathrm{N}=1579\end{array}$ & questionnaire & $\begin{array}{l}\text { Nurse aides enjoy working with residents and } \\
\text { co-workers but are not satisfied with pay }\end{array}$ \\
\hline $\begin{array}{l}\text { Castle, } \\
\text { Engberg, } \\
\text { Anderson, \& } \\
\text { Men } \\
2007 \\
\text { USA }\end{array}$ & Quantitative & $\begin{array}{l}1779 \text { aides in } \\
72 \text { nursing } \\
\text { homes in } 5 \\
\text { states }\end{array}$ & survey & $\begin{array}{l}\text { Job satisfaction is related to intent to leave and } \\
\text { turnover. Training, rewards and workload are } \\
\text { important aspects of nurse aide work }\end{array}$ \\
\hline
\end{tabular}




\begin{tabular}{|c|c|c|c|c|}
\hline $\begin{array}{l}\text { Castle, \& } \\
\text { Myers } \\
2006 \\
\text { USA }\end{array}$ & Quantitative & $\begin{array}{l}17,000 \text { nursing } \\
\text { homes }\end{array}$ & $\begin{array}{l}\text { Audit of deficiency } \\
\text { citations }\end{array}$ & $\begin{array}{l}\text { RN staffing is associated with lower likelihood of } \\
\text { being cited for deficiencies in mental health care. } \\
\text { NA staffing associated with greater likelihood of } \\
\text { deficiency citation in mental health care. }\end{array}$ \\
\hline $\begin{array}{l}\text { Caudill \& } \\
\text { Patrick } \\
1989 \\
\text { USA }\end{array}$ & Quantitative & & & $\begin{array}{l}\text { Praise by patient and family are important to aides. } \\
\text { Belonging to a peer group and praise by charge } \\
\text { nurse decreases turnover. Input into decisions } \\
\text { decreases turnover }\end{array}$ \\
\hline $\begin{array}{c}\text { Caudill \& } \\
\text { Patrick } \\
1991 \\
\text { USA }\end{array}$ & Quantitative & & & $\begin{array}{l}\text { Nursing assistants who plan to leave their jobs are } \\
\text { younger, had less tenure, were paid less, and were } \\
\text { better educated. Rotating assignments resulted in } \\
\text { more turnover than changing patient assignments } \\
\text { weekly or never. }\end{array}$ \\
\hline $\begin{array}{c}\text { Chappell, \& } \\
\text { Novak } \\
1992 \\
\text { Canada }\end{array}$ & Quantitative & $\begin{array}{l}25 \text { long term } \\
\text { care } \\
\text { institutions in } \\
\text { Winnipeg } \\
\text { Nursing } \\
\text { assistants } \\
\mathrm{N}=245\end{array}$ & $\begin{array}{l}\text { Aides complete the } \\
\text { Zarit Burden } \\
\text { inventory, Maslach } \\
\text { burden inventory and } \\
\text { work stress tool }\end{array}$ & $\begin{array}{l}\text { Aides who experience greater workload are more } \\
\text { likely to feel burdened. Social support at work does } \\
\text { not relieve the effect of workload. Aides who } \\
\text { receive support from family and friends are less } \\
\text { likely to burnout. Aides who have family supportive } \\
\text { of their work experience less job pressure. Fewer } \\
\text { family members at home results in less job pressure. }\end{array}$ \\
\hline $\begin{array}{l}\text { Chappell, \& } \\
\text { Novak } \\
1994 \\
\text { Canada }\end{array}$ & Quantitative & $\begin{array}{l}25 \text { LTC homes } \\
\text { in Winnipeg } \\
\text { Nursing } \\
\text { assistants } \\
\mathrm{N}=245\end{array}$ & $\begin{array}{l}\text { Face to face } \\
\text { interviews }\end{array}$ & $\begin{array}{l}\text { Findings point to the need to measure diagnoses and } \\
\text { behaviours separately. Three behaviours were } \\
\text { related to stress: being uncooperative, restless and } \\
\text { constant crying }\end{array}$ \\
\hline $\begin{array}{c}\text { Cohen-Mansfi } \\
\text { eld } \\
1995 \\
\text { USA }\end{array}$ & $\begin{array}{l}\text { Examination } \\
\text { of literature } \\
\text { about stress } \\
\text { in nursing } \\
\text { homes }\end{array}$ & & & $\begin{array}{l}\text { Offers a comprehensive model of long term nursing } \\
\text { care stress }\end{array}$ \\
\hline $\begin{array}{c}\text { Cole } \\
1989 \\
\text { British }\end{array}$ & Qualitative & $\begin{array}{l}12 \text { aides in one } \\
\text { mental hospital } \\
\text { and two elderly } \\
\text { care hospitals }\end{array}$ & Interviews & $\begin{array}{l}\text { Aides believe that they do much the same job as the } \\
\text { RN but get little acknowledgement }\end{array}$ \\
\hline $\begin{array}{c}\text { Coleman, } \\
\text { Looney, } \\
\text { O’Brien, } \\
\text { Zeigler, } \\
\text { Pastorino, \& } \\
\text { Turner } \\
2002 \\
\text { USA }\end{array}$ & Quantitative & Two facilities & $\begin{array}{l}\text { One facility }=\text { Eden } \\
\text { Alternative } \\
\text { Control facility }= \\
\text { traditional care }\end{array}$ & $\begin{array}{l}\text { No significant differences after one year: no } \\
\text { differences in infection rates, functional status, cost } \\
\text { of care. Aide workforce at each facility remained } \\
\text { unstable. Turnover increased during the period of } \\
\text { implementation of Eden Alternative. }\end{array}$ \\
\hline Cooper \& & Quantitative & Nurse aides $\mathrm{N}$ & Aides given facts on & Mean score $59 \%$. In comparison, high school \\
\hline
\end{tabular}




\begin{tabular}{|c|c|c|c|c|}
\hline $\begin{array}{l}\text { Cronin } \\
2000 \\
\text { USA }\end{array}$ & & $\begin{array}{l}=177 \text { in } 9 \\
\text { nursing homes }\end{array}$ & aging quiz & $\begin{array}{l}\text { graduates mean score } 57 \% \text {. Education and } \\
\text { advancement of nurse aides is neglected }\end{array}$ \\
\hline $\begin{array}{c}\text { Cooper, } \\
\text { Kaeser, } \\
\text { Montgomery, } \\
\text { \& Marion } \\
1991 \\
\text { USA }\end{array}$ & $\begin{array}{l}\text { Quasi-experi } \\
\text { mental }\end{array}$ & & $\begin{array}{l}\text { Before and after } \\
\text { intervention }\end{array}$ & $\begin{array}{l}\text { Positive effects of permanent resident assignment, } \\
\text { case management, resident centred schedules }\end{array}$ \\
\hline $\begin{array}{c}\text { Corazzini, } \\
\text { McConnell, } \\
\text { Rapp, \& } \\
\text { Anderson } \\
2004 \\
\text { USA }\end{array}$ & $\begin{array}{l}\text { A conceptual } \\
\text { framework of } \\
\text { the } \\
\text { decision-mak } \\
\text { ing processes } \\
\text { of aides }\end{array}$ & & & $\begin{array}{l}\text { Aides make choices about caring for demented } \\
\text { patients on a continuum from rational to intuitive, in } \\
\text { part because of the working environment. Some } \\
\text { decisions are not good decisions and may lead to } \\
\text { decreased quality of care. }\end{array}$ \\
\hline $\begin{array}{c}\text { Cotton \& } \\
\text { Tuttle } \\
1986 \\
\text { USA }\end{array}$ & $\begin{array}{l}\text { Literature } \\
\text { Review }\end{array}$ & & & $\begin{array}{l}\text { Studies of employee turnover: increases in pay } \\
\text { reduce turnover. Job satisfaction, satisfaction with } \\
\text { co-workers are negatively related to turnover. Age, } \\
\text { tenure, number of dependents negatively related to } \\
\text { turnover. Women more likely to leave than men. }\end{array}$ \\
\hline $\begin{array}{c}\text { Dewar, \& } \\
\text { Macleod-Clar } \\
\text { k } \\
1992 \\
\text { England } \\
\end{array}$ & $\begin{array}{l}\text { Review of } \\
\text { existing } \\
\text { literature }\end{array}$ & & & $\begin{array}{l}\text { There is a lack of clear definition of roles and there } \\
\text { are mixed feelings amongst "qualified staff" to the } \\
\text { "new helper role" }\end{array}$ \\
\hline $\begin{array}{c}\text { Dickson \& } \\
\text { Cole } \\
1987 \\
\text { British }\end{array}$ & Opinion & & & $\begin{array}{l}\text { Registered nurses have no clear ideas or } \\
\text { expectations of the support workers' roles. }\end{array}$ \\
\hline $\begin{array}{c}\text { Dougherty, } \\
\text { Preston, Jones, } \\
\text { \& Payne } \\
1992 \\
\text { USA }\end{array}$ & Quantitative & $\begin{array}{l}\text { Varied staff at } \\
\text { one state } \\
\text { geriatric long } \\
\text { term care } \\
\text { hospital } \\
\mathrm{N}=28\end{array}$ & $\begin{array}{l}\text { Log of exposure to } \\
\text { aggressive behaviour } \\
\text { for one month, } \\
\text { semi-structured } \\
\text { interviews, a detailed } \\
\text { accounting of one } \\
\text { exposure to } \\
\text { aggressive } \\
\text { behaviour, and } \\
\text { questionnaire }\end{array}$ & $\begin{array}{l}\text { Physical aggression was the most frequently } \\
\text { reported form of aggression and occurred mostly in } \\
\text { the mornings. Job satisfaction was negatively } \\
\text { affected by exposure to aggressive behaviour but } \\
\text { positively affected by educational level }\end{array}$ \\
\hline $\begin{array}{l}\text { Douglas, } \\
\text { Meleis, } \\
\text { Eribes, \& Kim } \\
1996 \\
\text { Mexico }\end{array}$ & Quantitative & $\begin{array}{l}\text { Mexican } \\
\text { nursing } \\
\text { assistants } \\
\mathrm{N}=59\end{array}$ & questionnaire & $\begin{array}{l}\text { Frequent stressors were interpersonal relations, } \\
\text { anguish, work overload and work environment }\end{array}$ \\
\hline
\end{tabular}




\begin{tabular}{|c|c|c|c|c|}
\hline $\begin{array}{l}\text { Eaton } \\
2000 \\
\text { USA }\end{array}$ & $\begin{array}{l}\text { Literature } \\
\text { review }\end{array}$ & & & $\begin{array}{l}\text { Low quality of care, low quality work environments. } \\
\text { Much of the work is invisible and not documented } \\
\text { or measured. Training minimal. Supervision } \\
\text { inadequate. Little information is shared. Many aides } \\
\text { choose this work despite poor working conditions. }\end{array}$ \\
\hline $\begin{array}{l}\text { Edwards } \\
1997 \\
\text { British }\end{array}$ & Opinion & & & $\begin{array}{l}\text { Aides are the backbone of health services and } \\
\text { perform the greatest part of basic care. Aides are } \\
\text { indispensable. Aides do the work. RNs organize the } \\
\text { work. }\end{array}$ \\
\hline $\begin{array}{l}\text { Evers, Tomic } \\
\text { \& Brouwers } \\
2002 \\
\text { The } \\
\text { Netherlands }\end{array}$ & Quantitative & $\begin{array}{l}\text { "Staff" caring } \\
\text { for residents in } \\
33 \text { homes for } \\
\text { the elderly } \\
n=551\end{array}$ & Two questionnaires & $\begin{array}{l}\text { Physical aggression of residents was found to have a } \\
\text { significant relationship to depersonalization (one of } \\
\text { three dimensions of burn-out). }\end{array}$ \\
\hline $\begin{array}{l}\text { Farrell Miller } \\
\qquad \begin{array}{c}1997 \\
\text { USA }\end{array}\end{array}$ & Qualitative & $\begin{array}{l}\text { All staff of one } \\
\text { dementia care } \\
\text { unit }\end{array}$ & Interviews analyzed & $\begin{array}{l}\text { Responses to physical aggression and the effects of } \\
\text { physical aggression on caregivers and on nursing } \\
\text { practice. Showering is the activity most likely to } \\
\text { provoke patient aggression. }\end{array}$ \\
\hline $\begin{array}{l}\text { Feder, } \\
\text { Komisar, \& } \\
\text { Niefled } \\
2000 \\
\text { USA }\end{array}$ & $\begin{array}{l}\text { Literature } \\
\text { review }\end{array}$ & & & Medicaid versus Medicare. \\
\hline $\begin{array}{l}\text { Feldt \& Ryden } \\
\qquad \begin{array}{c}1992 \\
\text { USA }\end{array}\end{array}$ & Quantitative & $\begin{array}{l}\text { Educational } \\
\text { intervention }\end{array}$ & & $\begin{array}{l}\text { Following educational intervention, aides report } \\
\text { caring for cognitively impaired residents is more } \\
\text { rewarding and less frustrating }\end{array}$ \\
\hline $\begin{array}{c}\text { Fitzwater \& } \\
\text { Gates } \\
2002 \\
\text { USA }\end{array}$ & Quantitative & 20 aides & Assault log & $\begin{array}{l}\text { Educational intervention to reduce resident assaults } \\
\text { on aides. } 4 \text { hour educational intervention resulted in } \\
\text { reduced number of assaults and increased } \\
\text { confidence. }\end{array}$ \\
\hline $\begin{array}{l}\text { Foner } \\
1994 \\
\text { USA }\end{array}$ & Qualitative & $\begin{array}{l}200 \text { bed } \\
\text { nursing home } \\
\text { in New York } \\
\text { City }\end{array}$ & $\begin{array}{l}\text { Ethnography } \\
\text { Participant } \\
\text { observation, } 14 \\
\text { "formal" interviews, } \\
20 \text { "informal } \\
\text { interviews }\end{array}$ & $\begin{array}{l}\text { Most nurse aides are kind and helpful to residents } \\
\text { most of the time. Many aides established relations } \\
\text { with patients that they and the patients found } \\
\text { gratifying. Work is physically straining and } \\
\text { emotionally wearing. Patients are bitter and hostile. } \\
\text { Abuse from patients. }\end{array}$ \\
\hline $\begin{array}{c}\text { Freyne \& } \\
\text { Wrigley } \\
1996 \\
\text { Ireland }\end{array}$ & Quantitative & & $\begin{array}{l}\text { Review systems of } \\
\text { recording aggressive } \\
\text { incidents, introduce } \\
\text { new system, review } \\
\text { all cases }\end{array}$ & $\begin{array}{l}\text { Aggression by patients is common. Staff require } \\
\text { support and acknowledgement of their difficulties } \\
\text { dealing with aggression. A reporting system may } \\
\text { assist staff to highlight factors associated with } \\
\text { aggression. }\end{array}$ \\
\hline $\begin{array}{l}\text { Friedman, } \\
\text { Daub, Cresci, }\end{array}$ & Quantitative & $\begin{array}{l}\text { Nurse aides in } \\
5 \text { nursing }\end{array}$ & Survey & $\begin{array}{l}\text { Compares Nurse aides in } 5 \text { home care programs to } \\
\text { nurse aides in } 5 \text { nursing homes. Job satisfaction is }\end{array}$ \\
\hline
\end{tabular}




\begin{tabular}{|c|c|c|c|c|}
\hline $\begin{array}{l}\text { \& Keyser } \\
1999 \\
\text { USA }\end{array}$ & & $\begin{array}{l}\text { homes and } 5 \\
\text { home care } \\
\text { programs } \\
\mathrm{N}=349\end{array}$ & & $\begin{array}{l}\text { higher in nurse aides in home care, probably due to } \\
\text { increased ability to use own judgments and make } \\
\text { own decisions }\end{array}$ \\
\hline $\begin{array}{l}\text { Garland, } \\
\text { Oyabu, \& } \\
\text { Gipson } \\
1988 \\
\text { USA }\end{array}$ & Opinion & & & $\begin{array}{l}\text { Careful screening of attitudes and values of aides } \\
\text { will reduce turnover }\end{array}$ \\
\hline $\begin{array}{l}\text { Gates, } \\
\text { Fitzwater, \& } \\
\text { Meyer } \\
1999 \\
\text { USA }\end{array}$ & Quantitative & & & $\begin{array}{l}\text { Violence occurs frequently. Caregivers and nursing } \\
\text { directors consider assaults against caregivers by } \\
\text { residents as violence. Homes do not have enough } \\
\text { policies or procedures in place to prevent, monitor } \\
\text { or control violence }\end{array}$ \\
\hline $\begin{array}{l}\text { Gates, } \\
\text { Fitzwater and } \\
\text { Succop } \\
2003 \\
\text { USA }\end{array}$ & Quantitative & $\begin{array}{l}\text { Nurse aides } \\
\mathrm{N}=138\end{array}$ & $\begin{array}{l}\text { Occupational stress } \\
\text { inventory and assault } \\
\log \end{array}$ & $\begin{array}{l}\text { Mean number of assaults per nurse aide per } 80 \text { hours } \\
\text { of work was } 4.69 \\
\text { Range } 0-67 \text { assaults per } 80 \text { hours of work }\end{array}$ \\
\hline $\begin{array}{c}\text { Gilloran, } \\
\text { McKinley, } \\
\text { McGlew, } \\
\text { McKee, \& } \\
\text { Robertson } \\
1994 \\
\text { Scotland }\end{array}$ & Quantitative & $\begin{array}{l}2080 \text { staff in } \\
\text { psychogeriatric } \\
\text { wards, } 50.1 \% \\
\text { of these were } \\
\text { nurse aides }\end{array}$ & questionnaire & $\begin{array}{l}\text { Staff nurses were more dissatisfied then nurse aides } \\
\text { because they did not want to be assigned to a } \\
\text { psychogeriatric ward. }\end{array}$ \\
\hline $\begin{array}{l}\text { Goldman } \\
1998 \\
\text { USA }\end{array}$ & Quantitative & 5 facilities & $\begin{array}{l}\text { Survey of staff } \\
\text { perceptions of } \\
\text { primary versus team } \\
\text { nursing }\end{array}$ & Staff prefer permanent assignments \\
\hline $\begin{array}{c}\text { Graneheim, } \\
\text { Isaksson, } \\
\text { Ljung, \& } \\
\text { Jansson } \\
2005 \\
\text { Sweden }\end{array}$ & Qualitative & $\begin{array}{l}\text { Six care } \\
\text { providers }\end{array}$ & $\begin{array}{l}\text { Narrative interviews: } \\
\text { phenomenological } \\
\text { hermeneutic }\end{array}$ & $\begin{array}{l}\text { Interactions with people suffering from dementia } \\
\text { and behavioural disturbances = ethical dilemmas, } \\
\text { balancing contradictions, feeling powerless versus } \\
\text { capable, feeling rejected versus accepted }\end{array}$ \\
\hline $\begin{array}{l}\text { Grant, Kane, } \\
\text { Potthoff, \& } \\
\text { Ryden } \\
1996 \\
\text { USA }\end{array}$ & Quantitative & $\begin{array}{l}400 \text { nursing } \\
\text { units in } 124 \\
\text { facilities }\end{array}$ & $\begin{array}{l}\text { Collection of } \\
\text { baseline data about } \\
\text { dementia specific } \\
\text { training programs }\end{array}$ & $\begin{array}{l}22 \% \text { of facilities had no dementia oriented training } \\
\text { for new staff. For nursing assistants, more training } \\
\text { increases their knowledge and skills needed to work } \\
\text { more effectively with residents with dementia }\end{array}$ \\
\hline $\begin{array}{l}\text { Grau, } \\
\text { Chandler, } \\
\text { Burton \& }\end{array}$ & Quantitative & $\begin{array}{l}\text { Nurse aides } \\
\mathrm{N}=219\end{array}$ & questionnaire & $\begin{array}{l}\text { Quality of the social environment of the nursing } \\
\text { home is as important as attitudes to job benefits in } \\
\text { accounting for institutional loyalty }\end{array}$ \\
\hline
\end{tabular}




\begin{tabular}{|c|c|c|c|c|}
\hline $\begin{array}{c}\text { Kolditz } \\
1991 \\
\text { USA }\end{array}$ & & & & \\
\hline $\begin{array}{c}\text { Grau \& } \\
\text { Wellin } \\
1992 \\
\text { USA }\end{array}$ & Qualitative & $\begin{array}{l}\text { Two } \\
\text { metropolitan } \\
\text { nursing homes }\end{array}$ & Ethnography & $\begin{array}{l}\text { Monticello versus Homehaven: Unaddressed } \\
\text { significant cultural, sociostructural and } \\
\text { sociodemographic characteristics shape the climate } \\
\text { of the organization }\end{array}$ \\
\hline $\begin{array}{l}\text { Grieshaber, } \\
\text { Parker, \& } \\
\text { Deering } \\
1995 \\
\text { USA }\end{array}$ & Quantitative & $\begin{array}{l}\text { Two nursing } \\
\text { homes }\end{array}$ & questionnaire & $\begin{array}{l}\text { Aides more likely to be dissatisfied with the working } \\
\text { conditions than the job content. Managerial } \\
\text { performance is key to job satisfaction. Supervisors } \\
\text { should include aides in care planning activities to } \\
\text { give aides an ownership stake }\end{array}$ \\
\hline $\begin{array}{c}\text { Hagen \& } \\
\text { Sayers } \\
1995 \\
\text { USA }\end{array}$ & Quantitative & & & $\begin{array}{l}\text { Physical aggression associated with lack of } \\
\text { knowledge. } 50 \% \text { reduction in reported physical } \\
\text { aggression from residents after a staff education } \\
\text { program }\end{array}$ \\
\hline $\begin{array}{l}\text { Hare \& Pratt } \\
\begin{array}{c}1988 \\
\text { USA }\end{array}\end{array}$ & Quantitative & $\begin{array}{l}\text { LPNs and RNs } \\
(\mathrm{n}=57) \text { and } \\
\text { aides }(\mathrm{n}=96)\end{array}$ & $\begin{array}{l}\text { Surveys } \\
\text { Burnout Inventory }\end{array}$ & $\begin{array}{l}\text { Aides experience significantly more emotional } \\
\text { exhaustion and significantly more depersonalization } \\
\text { than professional nurses. }\end{array}$ \\
\hline $\begin{array}{l}\text { Harrington } \\
2005 \\
\text { USA }\end{array}$ & Quantitative & $\begin{array}{l}\text { State licensing } \\
\text { and } \\
\text { certification } \\
\text { program } \\
\text { directors }\end{array}$ & $\begin{array}{l}\text { Collection of data } \\
\text { from internet } \\
\text { regarding state } \\
\text { regulations plus } \\
\text { telephone survey }\end{array}$ & $\begin{array}{l}\text { Florida is the state with highest nursing home } \\
\text { staffing levels: } 3.9 \text { hours per resident per day. A } \\
\text { trend across the USA towards higher staffing levels. } \\
33 \text { states have minimum staffing levels for NAs. No } \\
\text { federal minimum standards for NA staffing levels. }\end{array}$ \\
\hline $\begin{array}{l}\text { Harrington, } \\
\text { O’Meara, } \\
\text { Collier, \& } \\
\text { Schnelle } \\
2003 \\
\text { USA }\end{array}$ & Descriptive & & $\begin{array}{l}\text { Examination of } \\
\text { information on } \\
\text { public database of } \\
1400 \text { California } \\
\text { nursing homes }\end{array}$ & $\begin{array}{l}\text { Aides wages are less than a living wage. } 91 \% \text { of all } \\
\text { California nursing homes report nurse aide hours } \\
\text { below the recommended } 2.8 \text { hours per resident per } \\
\text { day. Average facility reported } 2.2 \text { hours per resident } \\
\text { per day. Average annual turnover rate is } 78 \% \text {. Only } \\
23 \% \text { of California facilities comply with federal } \\
\text { regulations }\end{array}$ \\
\hline $\begin{array}{l}\text { Harrington \& } \\
\text { Swan } \\
2003 \\
\text { USA }\end{array}$ & Quantitative & $\begin{array}{l}\text { Nursing } \\
\text { staffing data } \\
\text { from California } \\
\text { cost reports } \\
1999\end{array}$ & & $\begin{array}{l}\text { Total nursing hours per resident per day averages } \\
3.208 \text { hours. Higher proportions of Medicare } \\
\text { residents and lower proportions of Medicaid } \\
\text { residents = significantly higher staffing hours. For } \\
\text { profit facilities had less staffing hours. }\end{array}$ \\
\hline $\begin{array}{l}\text { Harrison, } \\
\text { Loiselle, } \\
\text { Duquette, \& } \\
\text { Semenic } \\
2002 \\
\text { Canada }\end{array}$ & Quantitative & $\begin{array}{l}\text { Aides in } \\
\text { Quebec, } n= \\
171\end{array}$ & $\begin{array}{l}\text { Self report } \\
\text { questionnaires }\end{array}$ & $\begin{array}{l}\text { Examine relationships between hardiness, } \\
\text { psychological distress and work support in nursing } \\
\text { aides compared to RNs. Aides are significantly less } \\
\text { hardy than RNs and more vulnerable to occupational } \\
\text { stressors and burnout }\end{array}$ \\
\hline Canadian & Highlights & Uses data & & Resident Assessment Instrument Minimum Data Set \\
\hline
\end{tabular}




\begin{tabular}{|c|c|c|c|c|}
\hline $\begin{array}{l}\text { Institute for } \\
\text { Health } \\
\text { Information: } \\
\text { Caring for } \\
\text { Residents with } \\
\text { Behavioural } \\
\text { Symptoms } \\
\text { Canada } \\
2008\end{array}$ & $\begin{array}{l}\text { the use of the } \\
\text { RAI MDS } \\
2.0 \text { used to } \\
\text { capture } \\
\text { aggression } \\
\text { and other } \\
\text { behavioural } \\
\text { symptoms. }\end{array}$ & $\begin{array}{l}\text { submitted by } 5 \\
\text { Nova Scotia } \\
\text { nursing homes }\end{array}$ & & $\begin{array}{l}\text { (RAI MDS). } \\
45 \% \text { of residents exhibit behavioural symptoms } \\
\text { including verbal or physical abuse, social } \\
\text { inappropriateness, resistance to care and wandering. }\end{array}$ \\
\hline $\begin{array}{c}\text { Canadian } \\
\text { Institute for } \\
\text { Health } \\
\text { Information: } \\
\text { Health Care in } \\
\text { Canada } \\
2007 \\
\text { Canada }\end{array}$ & $\begin{array}{l}\text { Produced } \\
\text { with } \\
\text { Statistics } \\
\text { Canada to } \\
\text { provide } \\
\text { current } \\
\text { information } \\
\text { on health } \\
\text { system and } \\
\text { health of } \\
\text { Canadians }\end{array}$ & & & $\begin{array}{l}\text { Health care costs, profile of the workforce } \\
\text { (professionals only, NOT aides), wait times for } \\
\text { procedures, mortality statistics (cardiac, infections, } \\
\text { mistakes etc.), life expectancy across the provinces }\end{array}$ \\
\hline $\begin{array}{c}\text { Health } \\
\text { Employers } \\
\text { Association of } \\
\text { British } \\
\text { Columbia } \\
2000 \\
\text { Canada }\end{array}$ & $\begin{array}{l}\text { Government } \\
\text { document } \\
\text { prepared for } \\
\text { Health } \\
\text { employers } \\
\text { association of } \\
\text { BC and } \\
\text { association of } \\
\text { unions. }\end{array}$ & 6 sites in $\mathrm{BC}$ & $\begin{array}{l}\text { Interviews, focus } \\
\text { groups and surveys }\end{array}$ & $\begin{array}{l}\text { Focuses mainly on LPNs. Provides } \\
\text { recommendations for new positions, education } \\
\text { programs, scholarship programs, and continuing } \\
\text { education for aides and LPNs. Plans were to provide } \\
\text { these recommendations to the Ministry of Health. }\end{array}$ \\
\hline $\begin{array}{l}\text { Heliker } \\
2007 \\
\text { USA }\end{array}$ & $\begin{array}{l}\text { Discussion/o } \\
\text { pinion }\end{array}$ & & $\begin{array}{l}\text { Story sharing } \\
\text { interventions } \\
\text { between nurse aides } \\
\text { and residents of one } \\
\text { long term care } \\
\text { facility }\end{array}$ & $\begin{array}{l}\text { Time allotted for reciprocity through story telling: } \\
\text { nurse aides feeling valued (best practice) }\end{array}$ \\
\hline $\begin{array}{c}\text { Helmer, } \\
\text { Olson, \& } \\
\text { Heim } \\
1993 \\
\text { USA }\end{array}$ & Quantitative & $\begin{array}{l}\text { Nurse aides in } \\
40 \text { nursing } \\
\text { homes } N=246\end{array}$ & Survey & $\begin{array}{l}71 \% \text { dissatisfied with wages } \\
70 \% \text { of nurse aides felt they received no respect } \\
64 \% \text { felt ignored by management }\end{array}$ \\
\hline $\begin{array}{l}\text { Hollinger-Sam } \\
\text { son, \& } \\
\text { Pearson } \\
2000\end{array}$ & Quantitative & $\begin{array}{l}62 \text { cognitively } \\
\text { intact residents } \\
\text { in } 6 \text { nursing } \\
\text { homes }\end{array}$ & $\begin{array}{l}\text { Empathy scales, } \\
\text { depression scales }\end{array}$ & $\begin{array}{l}\text { Examines resonated / perceived nurse aide empathy } \\
\text { (measured by empathy subscale), expressed empathy } \\
\text { (supervisors) with self rated depressive symptoms of } \\
\text { residents Negative nurse aide behaviour is related to }\end{array}$ \\
\hline
\end{tabular}




\begin{tabular}{|c|c|c|c|c|}
\hline USA & & & & negative psychological outcomes for residents. \\
\hline $\begin{array}{l}\text { Hsieh \& Su } \\
2007 \\
\text { Taiwan }\end{array}$ & Quantitative & 826 aides & Survey via telephone & $\begin{array}{l}\text { Major reasons for staying in LTC are personal } \\
\text { interest in caring, good financial benefits, supportive } \\
\text { supervisors. } \\
\text { Reasons for leaving: low wages, heavy workloads, } \\
\text { long hours, high levels of stress }\end{array}$ \\
\hline $\begin{array}{c}\text { Jackson } \\
1997 \\
\text { USA }\end{array}$ & Qualitative & $\begin{array}{l}52 \text { nurse aides, } \\
5 \text { nursing } \\
\text { homes }\end{array}$ & $\begin{array}{l}\text { Ethnography, } \\
\text { feminist methods }\end{array}$ & $\begin{array}{l}\text { Practical knowledge used to guide decision making. } \\
\text { A major barrier to giving care is the organization of } \\
\text { care itself. Not enough time to give adequate care. } \\
\text { Aides not monitored or supervised. Aides not } \\
\text { informed properly. Aides perform "invisible work". }\end{array}$ \\
\hline $\begin{array}{l}\text { Janz } \\
1992 \\
\text { USA }\end{array}$ & Opinion & & & $\begin{array}{l}\text { Aides would benefit from psychological training in } \\
\text { their programs. }\end{array}$ \\
\hline $\begin{array}{l}\text { Jervis } \\
2002 a \\
\text { USA }\end{array}$ & Qualitative & $\begin{array}{l}14 \text { residents } \\
\text { One trained } \\
\text { medication } \\
\text { aide, four NAs, } \\
11 \text { nursing } \\
\text { department } \\
\text { employees } \\
\text { (administration } \\
\text {, RNs, LPNs) }\end{array}$ & $\begin{array}{l}\text { Ethnography } \\
\text { Participant } \\
\text { observation, } \\
\text { semi-structured } \\
\text { interviews, medical } \\
\text { record reviews }\end{array}$ & $\begin{array}{l}\text { The study revealed a local work environment } \\
\text { characterized by conflict and by nurse aides } \\
\text { resistance to nurses' domination }\end{array}$ \\
\hline $\begin{array}{l}\text { Jervis } \\
2002 b \\
\text { USA }\end{array}$ & Qualitative & $\begin{array}{l}\text { One nursing } \\
\text { home for } \\
\text { psychiatrically } \\
\text { disabled } \\
\text { clientele. } 14 \\
\text { residents and } \\
16 \text { staff } \\
\text { members }\end{array}$ & $\begin{array}{l}\text { Ethnography: } \\
\text { Participant } \\
\text { observation } \\
\text { Semistructured } \\
\text { interviews }\end{array}$ & $\begin{array}{l}\text { An exploration of how staff conceptualized and } \\
\text { dealt with "problem" behaviours. } \\
\text { Staff were cognizant of the ever-present threat of } \\
\text { assault. Violent, serious disruptive behaviour is a } \\
\text { serious problem. Staff resorted to informal and } \\
\text { formal strategies. }\end{array}$ \\
\hline $\begin{array}{l}\text { Kettlitz, Zbib, } \\
\text { \& Motwani } \\
1997 \\
\text { USA }\end{array}$ & Quantitative & & & $\begin{array}{l}\text { To reduce turnover rates, it is important to reduce } \\
\text { the number of poor candidates selected for } \\
\text { employment by using a weighted application blank }\end{array}$ \\
\hline $\begin{array}{c}\text { Kim, \& } \\
\text { Rovner } \\
1995 \\
\text { USA }\end{array}$ & Opinion & & & $\begin{array}{l}\text { Nursing homes function as long term psychiatric } \\
\text { hospitals for the elderly }\end{array}$ \\
\hline $\begin{array}{c}\text { Kitson } \\
1987 \\
\text { USA }\end{array}$ & $\begin{array}{l}\text { Discussion of } \\
\text { case studies } \\
\text { Qualitative? }\end{array}$ & & & $\begin{array}{l}\text { The author offers a set of characteristics similar to } \\
\text { both lay-caring and professional caring relationships } \\
\text { and offers case studies to illustrate care-giving } \\
\text { features. }\end{array}$ \\
\hline
\end{tabular}




\begin{tabular}{|c|c|c|c|c|}
\hline $\begin{array}{l}\text { Kiyak, } \\
\text { Namazi, \& } \\
\text { Kahana } \\
1984 \\
\text { USA }\end{array}$ & Quantitative & $\begin{array}{l}308 \text { employees } \\
\text { of } 6 \text { nursing } \\
\text { homes and } 12 \\
\text { community } \\
\text { facilities }\end{array}$ & questionnaire & $\begin{array}{l}\text { Intention to leave is predicated by age (younger), } \\
\text { length of employment (shorter), job dissatisfaction } \\
\text { and community agency. }\end{array}$ \\
\hline $\begin{array}{c}\text { Kovach \& } \\
\text { Krejci } \\
1998 \\
\text { USA }\end{array}$ & Quantitative & Aides $=22$ & Card sort & $\begin{array}{l}50 \text { facility factors deemed important for quality care. } \\
\text { Staff working together as a team }=\# 1 \text {. Having } \\
\text { sufficient time to devote to patient care }=\# 2 \text {. Having } \\
\text { enough time to spend personal time with residents } \\
=\# 3 \text {. }\end{array}$ \\
\hline $\begin{array}{l}\text { Kristiansen, } \\
\text { Hellzen \& } \\
\text { Asplund. } \\
2006 \\
\text { Sweden }\end{array}$ & $\begin{array}{l}\text { Qualitative: } \\
\text { narrative } \\
\text { interviews }\end{array}$ & $\begin{array}{l}2 \text { RNs } \\
18 \text { support } \\
\text { workers }\end{array}$ & $\begin{array}{l}\text { Thematic content } \\
\text { analysis }\end{array}$ & $\begin{array}{l}\text { The organization and resident behaviours were seen } \\
\text { as very negative. A positive relationship with } \\
\text { colleagues was the primary reason for nurses } \\
\text { continuing to work. }\end{array}$ \\
\hline $\begin{array}{l}\text { Lin, Yin, \& Li } \\
2002 \\
\text { Taiwan }\end{array}$ & Quantitative & $\begin{array}{l}\text { Analysis of } \\
\text { work stressors } \\
\text { of } 102 \text { aides }\end{array}$ & Interview & $\begin{array}{l}\text { Patient care tasks most stressful. Type of } \\
\text { relationship with supervisor reported as least } \\
\text { stressful. }\end{array}$ \\
\hline $\begin{array}{c}\text { Liu } \\
2007 \\
\text { Taiwan }\end{array}$ & $\begin{array}{l}\text { Quantitative, } \\
\text { cross } \\
\text { sectional } \\
\text { design to } \\
\text { explore } \\
\text { factors that } \\
\text { influence job } \\
\text { satisfaction } \\
\text { of nurse aides } \\
\text { and the } \\
\text { influence of } \\
\text { job } \\
\text { satisfaction } \\
\text { on the clients }\end{array}$ & $\begin{array}{l}17 \text { private, } \\
\text { public and } \\
\text { freestanding } \\
\text { nursing homes } \\
\text { in } 3 \text { main cities } \\
\text { in Taiwan. } \\
\text { Nurse aides } n= \\
244 \text {, residents } \\
\text { and families, } n \\
=392 \text {. }\end{array}$ & $\begin{array}{l}40 \text { item } \\
\text { questionnaire for } \\
\text { nurse aides, } 10 \text { item } \\
\text { questionnaire for } \\
\text { residents and } \\
\text { families } \\
\text { Likert scale, very } \\
\text { satisfied to very } \\
\text { dissatisfied. }\end{array}$ & $\begin{array}{l}\text { Married, part time and nurse aides with long tenure } \\
\text { tended to be less satisfied. Justice and fairness were } \\
\text { viewed as the most important factors in work } \\
\text { environment. No correlation between job } \\
\text { satisfaction of NA and resident satisfaction }\end{array}$ \\
\hline $\begin{array}{c}\text { MacPherson, } \\
\text { Eastley, } \\
\text { Richards, \& } \\
\text { Mian } \\
1994 \\
\text { England }\end{array}$ & Quantitative & $\begin{array}{l}4 \text { long stay } \\
\text { wards, } 4 \text { homes } \\
\text { for elderly } \\
\text { mentally } \\
\text { infirm, } 4 \\
\text { homes for } \\
\text { elderly, } 4 \\
\text { private nursing } \\
\text { homes } \\
\mathrm{N}=188 \text { workers }\end{array}$ & $\begin{array}{l}\text { All staff in each unit } \\
\text { completed } 30 \text { item } \\
\text { screening } \\
\text { questionnaire } \\
\text { designed to measure } \\
\text { psychological } \\
\text { distress. } \\
\text { Additional log of } \\
\text { assaults over } \\
\text { previous week }\end{array}$ & $\begin{array}{l}\text { Very high rates of long term sickness. A relationship } \\
\text { between psychological disturbance and assault } \\
\text { during the past week. Disturbed staff were likely to } \\
\text { perceive lack of support at work and report } \\
\text { "shouting back" }\end{array}$ \\
\hline
\end{tabular}




\begin{tabular}{|c|c|c|c|c|}
\hline $\begin{array}{l}\text { Manthey } \\
1989 \\
\text { USA }\end{array}$ & Opinion & & & $\begin{array}{l}\text { The beginnings of the nurse aide working in } \\
\text { partnership with the RNs (as a dyad) resulting in } \\
\text { cost savings. Suggestion to pass cost savings on to } \\
\text { the RN in a form of salary increase. No salary } \\
\text { increase for aides. }\end{array}$ \\
\hline $\begin{array}{l}\text { Mattiasson \& } \\
\text { Andersson } \\
1997 \\
\text { Sweden }\end{array}$ & Quantitative & $\begin{array}{l}\text { Chronically ill } \\
\text { but cognitively } \\
\text { well residents } \\
(\mathrm{n}=60) \text { in } 13 \\
\text { homes }\end{array}$ & Questionnaires & $\begin{array}{l}54 \% \text { of residents indicated that staff members never } \\
\text { sat down and talked with them. Nursing homes do } \\
\text { not offer satisfactory opportunities for social } \\
\text { contact. }\end{array}$ \\
\hline $\begin{array}{l}\text { McAiney } \\
1998 \\
\text { Canada }\end{array}$ & Opinion & & & $\begin{array}{l}\text { Development of a model for nurse aide } \\
\text { empowermnent }\end{array}$ \\
\hline $\begin{array}{l}\text { McCarthy, } \\
\text { Blow \& Kales } \\
2004 \\
\text { USA }\end{array}$ & Quantitative & 9618 residents & $\begin{array}{l}\text { Use of } \\
\text { administrative data } \\
\text { for all residents in } \\
\text { VA nursing homes }\end{array}$ & $\begin{array}{l}17.9 \% \text { of residents are diagnosed with a serious } \\
\text { mental illness. Residents with a serious mental } \\
\text { illness and without dementia exhibit more verbal } \\
\text { disruption than residents with dementia. No } \\
\text { differences in physical aggression or socially } \\
\text { inappropriate behaviour. }\end{array}$ \\
\hline 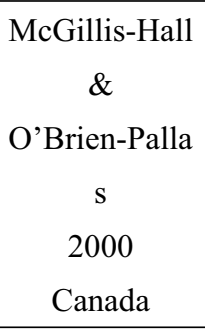 & Quantitative & $\begin{array}{l}\text { RNs } \mathrm{n}=14 \\
\text { RPNs } \mathrm{n}=11 \\
\text { Aides } \mathrm{n}=21 \\
\text { Toronto, } 2 \\
\text { nursing units }\end{array}$ & & $\begin{array}{l}\text { Although health care aides perform most of the } \\
\text { direct nursing care activities, they value it the least. } \\
\text { Aides value the performance of non-nursing tasks } \\
\text { and perceive their job as insignificant }\end{array}$ \\
\hline $\begin{array}{c}\text { McGilton, } \\
\text { O’Brien-Palla } \\
\text { s, Darlington, } \\
\text { Evans, Wynn, } \\
\text { \& Pringle } \\
2003 \\
\text { Canada }\end{array}$ & $\begin{array}{l}\text { Quasi-experi } \\
\text { mental }\end{array}$ & $\begin{array}{l}50 \text { residents } \\
\text { given } \\
\text { questionnaires, } \\
40 \text { residents } \\
\text { and } 34 \text { staff } \\
\text { observed }\end{array}$ & $\begin{array}{l}\text { Questionnaires and } \\
\text { observations }\end{array}$ & $\begin{array}{l}\text { Pre-post intervention: investigator designed } \\
\text { education program (relationship enhancing). Care } \\
\text { providers taught how to enhance relational skills } \\
\text { without added staff. Residents report significant } \\
\text { positive effects: more empathetic and more reliable. }\end{array}$ \\
\hline $\begin{array}{c}\text { McGrew } \\
1999 \\
\text { USA }\end{array}$ & Quantitative & $\begin{array}{l}15 \text { case studies } \\
\text { of residents in } \\
\text { long term care } \\
\text { who are } \\
\text { diagnosed with } \\
\text { serious mental } \\
\text { illness } \\
\text { excluding } \\
\text { dementias }\end{array}$ & $\begin{array}{l}\text { Chart audit } \\
\text { Resident interviews }\end{array}$ & $\begin{array}{l}\text { Violent, disruptive behaviours, agitation, anxiety, } \\
\text { withdrawal, conflict with staff, psychotic episodes, } \\
\text { impaired judgement, non-compliance with care } \\
\text { and/or facility regulations. Lack of training of staff } \\
\text { led to inconsistent responses and "taking the } \\
\text { behaviour personally" }\end{array}$ \\
\hline $\begin{array}{l}\text { Mercer, } \\
\text { Heacock \& } \\
\text { Beck }\end{array}$ & Quantitative & $\begin{array}{l}27 \text { randomly } \\
\text { selected aides } \\
\text { from } 3 \text { nursing }\end{array}$ & Interview & $\begin{array}{l}50 \% \text { of aides work extra shifts just to cover basic } \\
\text { expenses. } 77.7 \% \text { of aides experience discriminatory } \\
\text { language and racist behaviours. Slurs hurt, even if }\end{array}$ \\
\hline
\end{tabular}




\begin{tabular}{|c|c|c|c|c|}
\hline $\begin{array}{l}1993 \\
\text { USA }\end{array}$ & & homes & & $\begin{array}{l}\text { they come from demented residents. } 75 \% \text { report that } \\
\text { they need more training...feel inadequately trained } \\
\text { for the job. } \\
92 \% \text { of aides report verbal and physical abuse from } \\
\text { residents }\end{array}$ \\
\hline $\begin{array}{c}\text { Mesirow, } \\
\text { Klopp, \& } \\
\text { Olson } \\
1998 \\
\text { USA }\end{array}$ & Descriptive & & $\begin{array}{l}\text { Describes } \\
\text { implications of } \\
\text { enforcing an } \\
\text { attendance policy for } \\
\text { nurse aides }\end{array}$ & $\begin{array}{l}35 \% \text { reduction of sick time as a result of } \\
\text { implementing attendance policy }\end{array}$ \\
\hline $\begin{array}{c}\text { Moen \& } \\
\text { Nievaard } \\
1997 \\
\text { Dutch }\end{array}$ & Qualitative & $\begin{array}{l}15 \text { case studies } \\
\text { of dismissed } \\
\text { managers on } \\
\text { nursing homes }\end{array}$ & $\begin{array}{l}\text { Open, unstructured } \\
\text { interviews }\end{array}$ & $\begin{array}{l}\text { Managers have no early warning systems. Managers } \\
\text { create their own reality. Dismissal is based on } \\
\text { attitudes and competence, not on business expertise } \\
\text { or technical skills. Managers need training in social } \\
\text { skills. }\end{array}$ \\
\hline $\begin{array}{c}\text { Monahan \& } \\
\text { McCarthy } \\
1992 \\
\text { USA }\end{array}$ & Qualitative & $\begin{array}{l}\text { Views of aides } \\
\mathrm{n}=76 \text { in seven } \\
\text { rural nursing } \\
\text { homes in } \\
\text { Oregon }\end{array}$ & $\begin{array}{l}\text { Interviews } \\
\text { Content Analysis } \\
\text { Phenomenology? }\end{array}$ & $\begin{array}{l}\text { No particular reason for becoming a nurse aide } \\
\text { Like helping and working with people. Like feeling } \\
\text { needed, wanted, valued. Want to receive } \\
\text { recognition. Work is physically demanding, tiring. } \\
\text { Continue to work because need the money. Desire } \\
\text { for more autonomy. }\end{array}$ \\
\hline $\begin{array}{c}\text { Moyle, } \\
\text { Skinner, } \\
\text { Rowe, \& Gork } \\
2003 \\
\text { Australian }\end{array}$ & Qualitative & $\begin{array}{l}9 \text { RNs, } 5 \\
\text { students, } 13 \\
\text { aides }\end{array}$ & $\begin{array}{l}\text { Content analysis of } \\
\text { focus group } \\
\text { interviews }\end{array}$ & $\begin{array}{l}\text { Job satisfaction related to convenience, interaction } \\
\text { with residents, team environment, staying beyond } \\
\text { end of shift. Dissatisfaction related to being bullied } \\
\text { by others, unskilled staff, tensions within role } \\
\text { expectations, overtime, not being listened to. }\end{array}$ \\
\hline $\begin{array}{c}\text { National } \\
\text { Union of } \\
\text { Public and } \\
\text { General } \\
\text { Employees } \\
2007 \\
\text { Canada }\end{array}$ & $\begin{array}{l}\text { Discussion } \\
\text { and } \\
\text { presentation } \\
\text { of funding } \\
\text { issues for } \\
\text { LTC. } \\
\text { Discussion of } \\
\text { for profit } \\
\text { versus not for } \\
\text { profit. } \\
\text { Workplace } \\
\text { conditions }\end{array}$ & & & $\begin{array}{l}\text { Long term care not a fully insured health service in } \\
\text { any Canadian province or territory. Provides } \\
\text { demographics and useful facts. Monthly charges. } \\
\text { Guaranteed income supplement (GIS), low income. } \\
\text { System failing to provide many Canadians } \\
\text { affordable care. Many forced to pay for medical and } \\
\text { personal care, forced to spend assets. Poor staffing, } \\
\text { poor working conditions }\end{array}$ \\
\hline $\begin{array}{l}\text { Noelker, Ejaz, } \\
\text { Menne, Jones } \\
2006 \\
\text { USA }\end{array}$ & Quantitative & $\begin{array}{l}\text { Nurse aides } \\
\mathrm{N}=338 \text { at } 22 \\
\text { nursing homes }\end{array}$ & Survey data & $\begin{array}{l}\text { Personal stressors have the greatest impact on } \\
\text { satisfaction with supervision (family, financial, } \\
\text { health concerns). Personal stressors of NAs require } \\
\text { attention from supervisors because they affect } \\
\text { worker satisfaction }\end{array}$ \\
\hline Novak \& & Quantitative & Aides $n=245$ & Three subscales of & Frequency of disturbed patient behaviours explains \\
\hline
\end{tabular}




\begin{tabular}{|c|c|c|c|c|}
\hline $\begin{array}{l}\text { Chappell } \\
1994 \\
\text { Canada }\end{array}$ & & & burnout & $\begin{array}{l}\text { feelings of reduced personal accomplishment. Age, } \\
\text { minutes giving care, appraisal of work tasks, } \\
\text { reaction to patient behaviours explains } \\
\text { depersonalization }\end{array}$ \\
\hline $\begin{array}{c}\text { Nursing } \\
\text { Workforce: } \\
\text { Recruitment } \\
\text { and } \\
\text { Retention...Gr } \\
\text { owing } \\
\text { Concern } \\
\text { USA } \\
2001\end{array}$ & $\begin{array}{l}\text { Government } \\
\text { document } \\
\text { prepared for } \\
\text { statement to } \\
\text { Congress } \\
\text { Review of } \\
\text { current } \\
\text { literature }\end{array}$ & & & $\begin{array}{l}\text { Discussion of shortages, current and projected } \\
\text { supply of aides, factors contributing to shortage, } \\
\text { government and private efforts to improve } \\
\text { recruitment and retention of aides. Demographic, } \\
\text { employment, wage and benefit profiles in different } \\
\text { employment settings. }\end{array}$ \\
\hline $\begin{array}{l}\text { Parsons, } \\
\text { Simmons, } \\
\text { Penn, \& } \\
\text { Furlough } \\
2003 \\
\text { USA }\end{array}$ & Quantitative & $\begin{array}{l}\text { Aides from } 70 \\
\text { nursing homes } \\
\mathrm{N}=550\end{array}$ & Mail out survey & $\begin{array}{l}\text { Most satisfied with closeness to residents, their } \\
\text { affect on residents, belief that the job is important, } \\
\text { and own competence in providing resident care. } \\
\text { Dissatisfied with insufficient input into } \\
\text { decision-making, pay, benefits, recognition, } \\
\text { appreciation }\end{array}$ \\
\hline $\begin{array}{c}\text { Patchner \& } \\
\text { Patchner } \\
1993 \\
\text { USA }\end{array}$ & $\begin{array}{l}\text { Quasi-experi } \\
\text { mental }\end{array}$ & & Before-after & $\begin{array}{l}\text { Compares permanent assignment (primary care) to } \\
\text { rotating assignment (teams). Rotating distributes the } \\
\text { burden of difficult or care intensive patients. } \\
\text { Permanent assignment resulted in decreases in } \\
\text { behaviour problems and health outcomes and } \\
\text { decreased employee absenteeism. However aides } \\
\text { reported boredom and overly demanding residents }\end{array}$ \\
\hline $\begin{array}{l}\text { Radcliffe } \\
1995 \\
\text { USA }\end{array}$ & Opinion & & & $\begin{array}{l}\text { Increasing numbers of aides working in acute care } \\
\text { settings. Educators need to make an effort to assess, } \\
\text { organize, and plan activities for aides in acute care. }\end{array}$ \\
\hline $\begin{array}{l}\text { Ramirez, } \\
\text { Teresi, \& } \\
\text { Holmes } \\
2006 \\
\text { USA }\end{array}$ & Quantitative & $\begin{array}{l}22 \text { New York } \\
\text { State nursing } \\
\text { homes, } 104 \\
\text { aides }\end{array}$ & Interviews & $\begin{array}{l}27 \% \text { of nurse assistants reported pejorative name } \\
\text { calling by their residents. Pressure to complete task, } \\
\text { assignment size contributed to demoralization. } \\
\text { Support groups also contributed to demoralization } \\
\text { (negative support system) }\end{array}$ \\
\hline $\begin{array}{c}\text { Reagan } \\
1986 \\
\text { USA }\end{array}$ & Opinion & & & $\begin{array}{l}\text { Each administrator must regularly review to ensure } \\
\text { all aides have necessary training, skills and time to } \\
\text { perform their duties effectively and efficiently. }\end{array}$ \\
\hline $\begin{array}{c}\text { Redfern } \\
1994 \\
\text { British } \\
\end{array}$ & Opinion & & & $\begin{array}{l}\text { Many RNs feel threatened by increasing demand for } \\
\text { aides (support workers). RNs exercise control over } \\
\text { aides by delegating tasks to support workers. }\end{array}$ \\
\hline $\begin{array}{c}\text { Reeve } \\
1994 \\
\text { British }\end{array}$ & Quantitative & RNs $n=120$ & $\begin{array}{l}\text { Questionnaire survey } \\
\text { of } \mathrm{RN} \text { opinions of } \\
\text { aides }\end{array}$ & $\begin{array}{l}\text { RNs poorly informed about the role of the support } \\
\text { worker. }\end{array}$ \\
\hline Remsburg, & Quantitative & & & Tracking turnover without tracking stability rates \\
\hline
\end{tabular}




\begin{tabular}{|c|c|c|c|c|}
\hline $\begin{array}{c}\text { Armacost, \& } \\
\text { Bennett } \\
1999 \\
\text { USA }\end{array}$ & & & & results in an incomplete picture of aide turnover \\
\hline $\begin{array}{c}\text { Riggs, \& } \\
\text { Rantz } \\
2001 \\
\text { USA }\end{array}$ & $\begin{array}{l}\text { Review of } \\
\text { existing } \\
\text { literature and } \\
\text { opinion }\end{array}$ & & $\begin{array}{l}\text { A model of staff } \\
\text { support in nursing } \\
\text { homes is proposed }\end{array}$ & $\begin{array}{l}\text { An organization must provide structure and } \\
\text { leadership to help people work together productively }\end{array}$ \\
\hline $\begin{array}{l}\text { Salmon, } \\
\text { Crews, } \\
\text { Reynolds-Sca } \\
\text { nlon, Jang, } \\
\text { Weber, \& } \\
\text { Oakley } \\
1999 \\
\text { USA }\end{array}$ & $\begin{array}{l}\text { Literature } \\
\text { review of } \\
\text { research, } \\
\text { policy and } \\
\text { practice } \\
\text { regarding } \\
\text { nurse aide } \\
\text { turnover }\end{array}$ & & $\begin{array}{l}\text { Florida Policy } \\
\text { Exchange Centre on } \\
\text { Aging: sponsored } \\
\text { government } \\
\text { document. }\end{array}$ & $\begin{array}{l}\text { Stayers are older, African American women with } \\
\text { health and pension benefits. Wages and working } \\
\text { environments play a major role in turnover. Should } \\
\text { recruit older welfare to work clients and students. } \\
\text { Focus screening on questionnaires about skills, } \\
\text { motivations and reliability. Relationships are } \\
\text { important to job satisfaction and turnover. Aides } \\
\text { require clear job descriptions. }\end{array}$ \\
\hline $\begin{array}{l}\text { Sahyoun, } \\
\text { Pratt, } \\
\text { Lentzner, Dey, } \\
\text { \& Robinson } \\
2001 \\
\text { USA }\end{array}$ & $\begin{array}{l}\text { Profile of } \\
\text { nursing home } \\
\text { residents } \\
\text { 1985-1997 }\end{array}$ & & $\begin{array}{l}\text { Government report: } \\
\text { Center for Disease } \\
\text { Control and } \\
\text { Prevention }\end{array}$ & $\begin{array}{l}\text { Changing characteristics of residents. Older, more } \\
\text { racially diverse, more circulatory diseases and } \\
\text { cognitive and mental disorders, more mental health } \\
\text { issues, more help with ADLs, more incontinence, } \\
\text { increased choices of care (home care) }\end{array}$ \\
\hline $\begin{array}{l}\text { Schnelle, } \\
\text { Simmons, } \\
\text { Harrington, } \\
\text { Cadogan, } \\
\text { Garcia, \& } \\
\text { Bates-Jensen } \\
2004 \\
\text { USA }\end{array}$ & Quantitative & $\begin{array}{l}\text { Two groups of } \\
\text { nursing homes } \\
\mathrm{N}=21 \text { are } \\
\text { compared }\end{array}$ & $\begin{array}{l}\text { Chart audit, } \\
\text { Staff interviews, } \\
\text { direct observation }\end{array}$ & $\begin{array}{l}\text { Highest staffed nursing homes performed } \\
\text { significantly better on } 13 \text { of } 16 \text { care processes } \\
\text { implemented by nurse aides }\end{array}$ \\
\hline $\begin{array}{l}\text { Secrest, Iorio, } \\
\begin{array}{l}\text { \& Martz } \\
2005 \\
\text { USA }\end{array}\end{array}$ & Qualitative & $\begin{array}{l}\text { Why aides stay } \\
\text { in their jobs } \\
\text { Aides } n=11\end{array}$ & Indepth interviews & $\begin{array}{l}\text { Work is physically demanding, poor pay, work } \\
\text { grounded in hostility and disrespect, lack of control } \\
\text { and physical assaults by residents. Why aides stay in } \\
\text { long term care: a sense of connection with families, } \\
\text { residents and co-workers, pride, being recognized } \\
\text { for their efforts, being conscientious about details }\end{array}$ \\
\hline $\begin{array}{l}\text { Schnelle, } \\
\text { Simmons, } \\
\text { Harrington, } \\
\text { Cadogan, } \\
\text { Garcia, \& } \\
\text { Bates-Jensen }\end{array}$ & Quantitative & $\begin{array}{l}21 \text { nursing } \\
\text { homes in two } \\
\text { phases of the } \\
\text { study }\end{array}$ & $\begin{array}{l}\text { Staffing information } \\
\text { from data base, on } \\
\text { site interviews and } \\
\text { observations, plus } \\
\text { chart audit }\end{array}$ & $\begin{array}{l}\text { Authors describe quality of care related to } 27 \\
\text { different care processes ( } 16 \text { of the care processes } \\
\text { typically implemented by aides...feeding, } \\
\text { incontinence care, social engagement, repositioning } \\
\text { etc.). Highest staffed homes perform better on } 13 \text { of } \\
\text { the } 16 \text { care processes. Aides report lower care loads }\end{array}$ \\
\hline
\end{tabular}




\begin{tabular}{|c|c|c|c|c|}
\hline $\begin{array}{l}\text { USA } \\
2004\end{array}$ & & & & $\begin{array}{l}\text { and provide better care in homes with highest } \\
\text { staffing }\end{array}$ \\
\hline $\begin{array}{c}\text { Sheriden, } \\
\text { White, \& } \\
\text { Fairchild } \\
1992 \\
\text { USA }\end{array}$ & Quantitative & $\begin{array}{l}530 \text { staff in } 25 \\
\text { nursing homes } \\
\text { in Florida and } \\
\text { Texas }\end{array}$ & questionnaire & $\begin{array}{l}\text { Failed homes have significantly lower scores on } \\
\text { human relations climate dimensions and on } \\
\text { laissez-faire climate. } \\
\text { Management in failed homes inattentive to staff } \\
\text { motivation, demonstrating inadequate planning and } \\
\text { showing disdain for aides }\end{array}$ \\
\hline $\begin{array}{l}\text { Shaw } \\
2004 \\
\text { USA }\end{array}$ & Qualitative & $\begin{array}{l}9 \text { aides, } 3 \text { RNs, } \\
3 \\
\text { administrators } \\
\text { in } 6 \text { facilities }\end{array}$ & $\begin{array}{l}\text { Grounded theory } \\
\text { Semi-structured } \\
\text { interviews }\end{array}$ & $\begin{array}{l}\text { Nursing home staff responses to aggressive } \\
\text { residents. } \\
\text { Best practices: proactive, vigilance, being intuitive, } \\
\text { strategizing }\end{array}$ \\
\hline $\begin{array}{c}\text { Sherrell, } \\
\text { Anderson, \& } \\
\text { Buckwalter } \\
1998 \\
\text { USA }\end{array}$ & Quantitative & $\begin{array}{l}\text { Retrospective } \\
\text { audit of } \\
\text { psychological } \\
\text { reports of } 570 \\
\text { residents in } 51 \\
\text { nursing homes } \\
\text { in Chicago }\end{array}$ & $\begin{array}{l}\text { Coding and } \\
\text { categorizing of } \\
\text { narrative data } \\
\text { contained in reports }\end{array}$ & $\begin{array}{l}\text { Nursing homes function as long term psychiatric } \\
\text { hospitals for the elderly. High prevalence of mental } \\
\text { disorders in nursing homes. }\end{array}$ \\
\hline $\begin{array}{l}\text { Stone } \\
2004 \\
\text { USA }\end{array}$ & Opinion & & & $\begin{array}{l}\text { Recruitment and retention of aides is a major } \\
\text { problem. Policy makers must partner with providers, } \\
\text { organizations, and researchers to work towards } \\
\text { sustaining this workforce. }\end{array}$ \\
\hline $\begin{array}{c}\text { Sung, } \\
\text { Chang, \& } \\
\text { Tsai } \\
2005 \\
\text { Taiwan } \\
\end{array}$ & Qualitative & $\begin{array}{l}\text { Nurse aides } \\
\mathrm{N}=16\end{array}$ & $\begin{array}{l}\text { Semi-structured } \\
\text { interviews }\end{array}$ & $\begin{array}{l}\text { Emotional attachment to residents, cleanliness of the } \\
\text { environment, adequate staffing, training and } \\
\text { equipment contributed to increased job satisfaction }\end{array}$ \\
\hline $\begin{array}{c}\text { Task Force on } \\
\text { Resident/Staff } \\
\text { Ratio in } \\
\text { Nursing } \\
\text { Homes } \\
2002 \\
\text { Canada }\end{array}$ & $\begin{array}{l}\text { Government } \\
\text { document: } \\
\text { Canadian } \\
\text { Union of } \\
\text { Public } \\
\text { Employees } \\
\text { and Nova } \\
\text { Scotia Dept. } \\
\text { of Health }\end{array}$ & & $\begin{array}{l}\text { Survey of nursing } \\
\text { homes in Nova } \\
\text { Scotia }\end{array}$ & $\begin{array}{l}\text { Task force review of current nursing home staffing } \\
\text { in Nova Scotia and examination of challenges } \\
\text { (recruitment, increasing needs of residents, } \\
\text { inadequate levels of staffing. } \\
\text { No overall plan, no regular reporting of statistics. } \\
\text { Results compared to } 7 \text { of } 9 \text { provinces: Hours of care } \\
\text { provided in Nova Scotia generally less other } \\
\text { provinces. All provinces identify recruitment and } \\
\text { retention in top three issues. }\end{array}$ \\
\hline $\begin{array}{c}\text { Tellis-Nayak, } \\
\& \\
\text { Tellis-Nayak } \\
1989 \\
\text { USA }\end{array}$ & Qualitative & $\begin{array}{l}\text { Examines two } \\
\text { worlds of nurse } \\
\text { aides: world in } \\
\text { which they live } \\
\text { and world in }\end{array}$ & ethnography & A self perpetuating negative cycle \\
\hline
\end{tabular}




\begin{tabular}{|c|c|c|c|c|}
\hline & & $\begin{array}{l}\text { which they } \\
\text { work }\end{array}$ & & \\
\hline $\begin{array}{l}\text { Thornley } \\
2000 \\
\text { British }\end{array}$ & $\begin{array}{l}\text { Quantitative } \\
\text { and opinion }\end{array}$ & & $\begin{array}{l}\text { Author draws from } \\
\text { national } \\
\text { questionnaire } \\
\text { surveys }\end{array}$ & $\begin{array}{l}\text { Aides perceive themselves as substituting for } \\
\text { registered nurses. Aides are mature, experiences, } \\
\text { competent. RNs should welcome aides as team } \\
\text { members }\end{array}$ \\
\hline $\begin{array}{l}\text { Thorson } \\
1989 \\
\text { USA }\end{array}$ & $\begin{array}{l}\text { Letter to the } \\
\text { Editor }\end{array}$ & & & $\begin{array}{l}\text { The author responds positively to Tellis-Nayak } \\
\text { (1989) and concurs that aides are underpaid, } \\
\text { overworked and underappreciated. The author } \\
\text { reflects on his experiences as an orderly in Chicago. }\end{array}$ \\
\hline $\begin{array}{l}\text { Wadensten } \\
2005 \\
\text { Swedish }\end{array}$ & Qualitative & $\begin{array}{l}\text { Nurses } n=3 \\
\text { Aides } n=15 \\
\text { Residents } n= \\
20\end{array}$ & $\begin{array}{l}\text { Observations of } \\
\text { interactions and field } \\
\text { notes. Content } \\
\text { analysis }\end{array}$ & $\begin{array}{l}\text { Most common topic of conversation is sickness, } \\
\text { focused on the body. Conversations should not focus } \\
\text { on illness and body fixation. Staff hurry } \\
\text { conversations due to time constraints }\end{array}$ \\
\hline $\begin{array}{c}\text { Waxman, } \\
\text { Carner, \& } \\
\text { Berkenstock } \\
1984 \\
\text { USA }\end{array}$ & Quantitative & $\begin{array}{l}335 \text { aides in } \\
\text { seven nursing } \\
\text { homes }\end{array}$ & $\begin{array}{l}\text { Questionnaire and } \\
\text { various scales }\end{array}$ & $\begin{array}{l}\text { Turnover would lessen with changes in management } \\
\text { style that allow aides more involvement in the } \\
\text { decision-making process }\end{array}$ \\
\hline $\begin{array}{l}\text { Weech-Malon } \\
\text { ado, } \\
\text { Meret-Hanke, } \\
\text { Neff, \& Mor } \\
2004 \\
\text { USA }\end{array}$ & Quantitative & $\begin{array}{l}1135 \text { nursing } \\
\text { homes in } 5 \\
\text { states }\end{array}$ & $\begin{array}{l}\text { Data from minimum } \\
\text { data set (MDS) and } \\
\text { OSCAR }\end{array}$ & $\begin{array}{l}\text { Relationship between staffing and quality of care } \\
\text { outcomes (ulcers, restraints, psychotropic } \\
\text { medication, decline) is complex and more than a } \\
\text { matter of minimum staffing levels }\end{array}$ \\
\hline $\begin{array}{l}\text { Williams, } \\
\text { Kemper, \& } \\
\text { Humer } \\
2003 \\
\text { USA }\end{array}$ & Qualitative & $\begin{array}{l}20 \text { aides in } 5 \\
\text { nursing homes } \\
\text { attend a one } \\
\text { hour session }\end{array}$ & $\begin{array}{l}\text { Before-after analysis } \\
\text { of tape recordings of } \\
\text { speech }\end{array}$ & $\begin{array}{l}\text { Investigation of effectiveness of brief } \\
\text { communication program aimed at reducing } \\
\text { patronizing speech by aides. After training, aides } \\
\text { used fewer diminutives. }\end{array}$ \\
\hline $\begin{array}{l}\text { Wright } \\
1988 \\
\text { USA }\end{array}$ & Opinion & & & $\begin{array}{l}\text { Nursing home staff attitudes are inappropriately } \\
\text { measured with scales based on negative stereotypes. } \\
\text { Negative attitudes are not a credible explanation for } \\
\text { poor care }\end{array}$ \\
\hline $\begin{array}{l}\text { Wright } \\
2006 \\
\text { England }\end{array}$ & $\begin{array}{l}\text { Quantitative } \\
\text { and } \\
\text { Qualitative }\end{array}$ & $\begin{array}{l}\text { Nurse aides } \\
n=23\end{array}$ & $\begin{array}{l}\text { Questionnaire } \\
\text { supplied to nurse } \\
\text { aides post study day }\end{array}$ & $\begin{array}{l}\text { Study day helps nurse aides to understand their role } \\
\text { in supporting student nurses in geriatric settings }\end{array}$ \\
\hline $\begin{array}{l}\text { Workman } \\
1996 \\
\text { Britain }\end{array}$ & Qualitative & $\begin{array}{l}\text { Eight support } \\
\text { workers }\end{array}$ & $\begin{array}{l}\text { Semi-structured } \\
\text { interviews }\end{array}$ & $\begin{array}{l}\text { RNs regarded support workers as a threat. Support } \\
\text { workers perceived themselves as key players who } \\
\text { support the work of the RNs }\end{array}$ \\
\hline Yeatts \& & Mixed & Observe & Pre-test, post-test & 5 home have work teams, 5 homes give traditional \\
\hline
\end{tabular}




\begin{tabular}{|c|c|c|c|c|}
\hline $\begin{array}{c}\text { Cready } \\
2007 \\
\text { USA }\end{array}$ & $\begin{array}{l}\text { methods } \\
\text { (qualitative } \\
\text { and } \\
\text { quantitative) }\end{array}$ & $\begin{array}{l}\text { meetings } \\
\mathrm{n}=270 \text { in } 5 \\
\text { pairs of nursing } \\
\text { homes }\end{array}$ & $\begin{array}{l}\text { design: observations } \\
\text { of team meetings } \\
\text { and comparison of } \\
\text { nursing homes }\end{array}$ & $\begin{array}{l}\text { care. Work teams have modest positive effects: } \\
\text { increased empowerment, better aide performance, } \\
\text { improved care and choices, improved cooperation } \\
\text { and coordination. Possibly reduced turnover. }\end{array}$ \\
\hline $\begin{array}{c}\text { Yeatts, } \\
\text { Cready, Ray, } \\
\text { DeWitt, \& } \\
\text { Queen } \\
2004 \\
\text { USA }\end{array}$ & $\begin{array}{l}\text { Quasi-experi } \\
\text { mental }\end{array}$ & $\begin{array}{l}5 \text { nursing } \\
\text { homes in } \\
\text { Dallas-Fort } \\
\text { Worth: } \\
\text { comparison of } \\
\text { self managed } \\
\text { work teams for } \\
\text { nurse aides } \\
\text { versus no } \\
\text { teams }\end{array}$ & & $\begin{array}{l}\text { Qualitative analysis shows positive effects of self } \\
\text { managed work teams for nurse aides }\end{array}$ \\
\hline $\begin{array}{l}\text { Zinn } \\
1993 \\
\text { USA }\end{array}$ & Quantitative & & & $\begin{array}{l}\text { Facilities employ more NAs in markets where RN } \\
\text { wages are higher }\end{array}$ \\
\hline
\end{tabular}

Table 2. Abstraction and Grouping

Findings

\# of Reports

Factors that Compromise the Aides Abilities to provide Quality Care to Residents

There is not enough time to give sufficient care to residents (Krovach \& Krejci, 1998)

There is not enough time to have a personal relationship with residents (Krovach \& Krejci, 1998)

Lack of interaction or communication between aides and RNs or other professionals (Anderson et al. 2005)

Nurse aides interacting mainly with other nurse aides resulting in small cliques (Anderson, Bailey, Corazzini, \& Piven, 2005)

No rewards for performance (Anderson, Bailey, Corazzini, \& Piven, 2005)

Heavy reliance on rules and enforcement of rules (Grau and Wellin, 1992)

Having to cutting corners (Jervis, 2002a)

Lack of supervision (Barney, 1983)

Having to work alone (Barney, 1983)

High turnover rate (Barry, Brannon, \& Mor, 2005)

Recruitment difficulties (Beck, Ortigara, Mercer, \& Shue, 1999)

Lack of involvement of aides in the care planning process (Beck, Ortigara, Mercer, \& Shue, 1999) 2

Inadequate staffing levels (Beck, Ortigara, Mercer, \& Shue, 1999)

Components of training programs differ widely (Beck, Ortigara, Mercer, \& Shue, 1999) 1

Low wages (Jervis, 2002a)

Poor management of chronic pain (Schnell, Simmons, Harrington, Cadogan, Garcia, \& Bates-Jensen, 2004) 1

Workers perceive organizational climate as laissez faire (Sheridan, White, \& Fairchild, 1992)

Administration ignores the social history behind apathy (Tellis-Nayak \& Tellis-Nayak, 1989) 
Administration demonstrates inadequate planning (Sheridan, White, \& Fairchild, 1992)

Administration provides inadequate resources to enhance the quality of

resident care (Sheridan, White, \& Fairchild, 1992)

Administration show disdain for lower level caregivers (Sheridan, White, \& Fairchild, 1992) 4

The first priority of the aide is not high quality care, but survival in a hostile environment (Thorson, 1989) 1

Lack of depth of communication between aides and residents (Carpiac-Claver \& Levy-Storms, 2007) 2

Lower levels of RN staffing related to higher mental health deficiency citations (Castle \& Myers, 2006)

Factors that Enhance the Aides Abilities to provide Quality Care to Residents

Permanent assignment to residents (primary nursing) (Patchner \& Patchner, 1993) 1

Team work assignment (Foner, 1994) 5

Wisdom gained through the experience of being a mother (Anderson et al. 2005) 1

Aides responding to residents as they would wish someone would respond to them (Anderson et al. 2005)

Aides possess 'raw data' that can be interpreted by RNs for the residents' benefit (Anderson et al. 2005) 1

Interactions between administration, staff, and residents have a family or social quality (Barney, 1983) 4

Aides treated fairly (Barney, 1983) 1

Aides receive rewards (Monahan \& McCarthy, 1992) 3

Community involvement (the surrounding community's presence palpable in the home) (Barney, 1983) 1

Cultural homogeneity within the home (Grau, \& Wellin, 1992) 3

Caring relationships between aides and residents (Bowers, Esmond, \& Jacobson, 2000) 1

Management mechanisms (monitoring, measuring) (Schnell, Simmons, Harrington, Cadogan, Garcia, \& Bates-Jensen, 2004)

Administration that is sensitive to the social needs of the nurse aide (Tellis-Nayak \& Tellis-Nayak, 1989)

Administration that nurtures idealism (Tellis-Nayak \& Tellis-Nayak, 1989) 1

Administration that fosters a family spirit (Tellis-Nayak \& Tellis-Nayak, 1989) 1

Administration that boosts the self esteem of the aide (Tellis-Nayak \& Tellis-Nayak, 1989) 1

Focusing less on health status in conversation with residents, and more on resident as person (Wadensten, 2005) 1

Higher levels of RN staffing reduce the likelihood of receiving a mental health deficiency citation (Castle \& Myers,

\section{Characteristics of the Role}

Task diversity (Dewar \& McCleod-Clark, 1992) 2

Working without a clear job description (Ahmed \& Kitson, 1993) 3

Working with only minimal supervision (Eaton, 2000) 3

Doing more than what is on the job description (Dewar \& McCleod-Clark, 1992) 2

Feelings of depersonalization or devaluation (Bowers, Esmond, \& Jacobson, 2003) 4

Feelings of domination (Dewar \& McCleod-Clark, 1992) 1

Dog's body (Dewar \& McCleod-Clark, 1992) 1

Multiple simultaneous demands (Eaton, 2000) 3

Equipment and essential supplies frequently unavailable (Eaton, 2000)

Minimal information sharing (Eaton, 2000) 1

Multiple components of invisible work (neither measured nor documented) (Eaton, 2000) 2

Inadequate time to complete care (Eaton, 2000) 7

Physically straining work (Foner, 1994) 4

Emotionally wearing (Foner, 1994) 3 
Having to cope with physical or psychological abuse (Foner, 1994)

Repetitive work (Brannon et al. 1988)

Status hierarchies (Brannon et al. 1988)

\section{Turnover}

Average annual turnover rate for aides 1996 (in US) is 32\% (Banaszak-Holl \& Hines, 1996)

Average annual turnover rate for aides 2001 (in US) is 78\% (Harrington, O’Meara, Collier, \& Schnelle, 2003)

Average annual turnover rate for aides (California) is 78\% (Harrington, O’Meara, Collier, \& Schnelle, 2003)

$5 \%$ of homes have $75 \%$ annual turnover rate for aides (Banaszak-Holl \& Hines, 1996)

\section{Organizational Factors}

$62 \%$ of homes use primary resident care assignment (Banaszak-Holl \& Hines, 1996)

No federal standards for minimum levels of nurse aide staffing (in US) (Harrington, 2005)

Thirty three states have state minimum levels of nurse aide staffing (in US) (Harrington, 2005)

Florida is the state with the highest minimum levels of nurse aide staffing (Harrington, 2005)

The labour market for nurse aides is wage sensitive (Harrington \& Swan, 2003)

$44 \%$ of California nursing homes fail to meet state minimum standards for nurse aide staffing (Harrington, O’Meara,

Collier, \& Schnelle, 2003)

$62 \%$ of homes in California 1999 -2002 had serious deficiencies not in compliance with federal regulations (Harrington,

O’Meara, Collier, \& Schnelle, 2003)

\section{Training}

Minimal training (Eaton, 2000)

Working without any formal training (Dewar \& McCleod-Clark, 1992)

Orientation to the job: (in US) average less than one week (Banaszak-Holl \& Hines, 1996)

$75 \%$ feel inadequately trained for the job (Mercer, Heacock, \& Beck, 1993)

Federally mandated 75 hour initial training course in US (Castle, Engberg, Anderson, \& Men, 2007)

160 hours training and examination in California (Harrington, O’Meara, Collier, \& Schnelle, 2003)

Taiwan: minimum 100 hours of training and certification exam (Sung, Chang, \& Tsai, 2005)

Taiwan: not all aides receive minimum training and certificates (Sung, Chang, \& Tsai, 2005)

Some on the job training (Mexico) (Douglas, Meleis, Eribes, \& Kim, 1996)

\section{Wages}

Less than a living wage, not competitive with fast food industry (in US) (Harrington, O’Meara, Collier, \& Schnelle, 2003)

Having to work extra shifts or having a second job to cover basic expenses (Mercer, Heacock, \& Beck, 1993) 1

1991 US hourly wage in New York City \$9.16 (Grau, Chandler, Burton, \& Kolditz, 1991)

1993 average US net weekly income \$301.00 (Mercer, Heacock, \& Beck, 1993)

1993 average US hourly wage \$4.29 (Mercer, Heacock, \& Beck, 1993)

1995 average US hourly wage $\$ 5.60$ (Banaszak-Holl \& Hines, 1996) 
Taiwan: foreign workers will work for $1 / 2$ to $2 / 3$ of the salary paid to Taiwanese workers (Sung, Chang, \& Tsai, 2005)

Taiwan: foreign workers work for 12 hours per day compared to 8 hours for Taiwanese workers (Sung, Chang, \& Tsai, 2005)

2002 Taiwan monthly wage $\$ 571$ US dollars to $\$ 857$ US dollars (less than service industries) (Hsieh \& Su, 2007)1

Twenty five 10 hour days per month with 4-5 days off per month (Taiwan) (Hsieh \& Su, 2007)

\section{Demographics}

93\% women (Canada) (Chappell \& Novak, 1994)

$83 \%$ women (Taipei) (Hsieh \& Su, 2007)

Average age 48 years (Taipei) (Hsieh \& Su, 2007)

$80 \%$ education less than high school (Taipei) (Hsieh \& Su, 2007)

$35 \%$ of aides report health problems (Canada) (Chappell \& Novak, 1994)

$55 \%$ of aides report at least one sick day in bed over the past 6 months (Canada) (Chappell \& Novak, 1994) 1

$47 \%$ of aides use analgesics in the past week (Canada) (Chappell \& Novak, 1994)

In US: largely African-American or Hispanic (Banaszak-Holl \& Hines, 1996)

In Taiwan: mainly from the Philippines and Indonesia (Sung, Chang, \& Tsai, 2005)

\section{Aspects of Experience of Assault}

Most assaults occur during basic care activities (Gates, Fitzwater, \& Succop, 2003)

More than half of aides report receiving an injury from a resident at some point in employment (Fitzwater \& Gates, 2002)

Mean number of assaults per 80 hours work is 4.69 (Gates, Fitzwater, \& Succop, 2003)

$5 \%$ of assaults result in an injury (nature not specified) (Gates, Fitzwater, \& Succop, 2003)

$55 \%$ of assaults result in bruises, abrasions or scratch marks (Freyne \& Wrigley, 1996)

In $61 \%$ of assaults on aides, no specific action is taken after the incident (Freyne \& Wrigley, 1996)

Younger aides experience more assaults (Gates, Fitzwater, \& Succop, 2003)

Aides with negative attitudes experience more assaults (Gates, Fitzwater, \& Succop, 2003)

Aides with complaints of physical illnesses or poor self care habits experience more assaults (Gates, Fitzwater, \&

Succop, 2003)

Aides with more state anger (angry feelings, perceiving unfair treatment) experience more assaults (Gates, Fitzwater, \& Succop, 2003)

Residents with mental illnesses (but without dementia) exhibit more verbal disruption than residents with dementia (and without mental illness) (McCarthy, Blow, \& Kales, 2004)

Training helps aides feel more confident in ability to prevent assaults (Fitzwater \& Gates, 2002)

Education can decrease the number of assaults against caregivers (Fitzwater \& Gates, 2002)

\section{Factors Specifically Pertaining to Increased Job Satisfaction}

Teamwork (being a member of a team) (Krovach \& Krejci, 1998)

A network of interpersonal (collegial) relationships (Brannon, Cohn, \& Smyer, 1990) 5

Working in a community based program rather than in a facility (Friedman, Daub, Cresci, \& Keyser, 1999) 1

Administrative support (Krovach \& Krejci, 1998)

Relationships with residents (Bowers, Esmond, \& Jacobson, 2000)

Being able to provide care in a way that is like family (Bowers, Esmond, \& Jacobson, 2000) 
Belief that one is able to affect residents (Parsons, Simmons, Penn, \& Furlough, 2003)

Belief that one is competent in providing care (Parsons, Simmons, Penn, \& Furlough, 2003)

Flexible shifts that allow for better family life (Moyle, Skinner, Rowe, \& Gork, 2003)

Habitually staying beyond the end of the shift (Moyle, Skinner, Rowe, \& Gork, 2003)

Being formally recognized as supporting students and training students (Wright, 2006)

Homes with higher daily aide hours per resident (Anderson, Corazzini, \& McDaniel, 2004)

Variety in the work (Friedman, Daub, Cresci, \& Keyser, 1999)

Involvement in care planning activities (Friedman, Daub, Cresci, \& Keyser, 1999)

Having less formal education (Grau, Chandler, Burton, \& Kolditz, 1991)

Being older (Grau, Chandler, Burton, \& Kolditz, 1991)

Lower annual household income (Grau, Chandler, Burton, \& Kolditz, 1991)

Agreeable working conditions more important than job content (Grieshaber, Parker, \& Deering, 1995)

Factors Specifically Pertaining to Reduced Job Satisfaction

Permanent assignment to residents (primary nursing) results in boredom (Patchner \& Patchner, 1993)

Families who direct the work of the nurse aides (Grau \& Wellin, 1992)

Nurse aides perceive that RNs do not recognize their contributions (Ahmed \& Kitson, 1993)

Low wages (Brannon, Cohn, \& Smyer, 1990)

Low skill variety (Brannon, Cohn, \& Smyer, 1990)

Care routines that tend toward mass production (Brannon, Streit, \& Smyer, 1992)

Being unable to customize care for residents (Brannon, Streit, \& Smyer, 1992)

Feeling under-recognized or underappreciated (Jervis, 2002a)

Feeling over-monitored (Jervis, 2002a)

No involvement in decision-making or making changes or improvements (Parsons, Simmons, Penn, \& Furlough, 2003)

Lack of benefits (Parsons, Simmons, Penn, \& Furlough, 2003)

Low rewards (Lui, 2007)

Lack of control (Monahan \& McCarthy, 1992)

Lack of autonomy (Monahan \& McCarthy, 1992)

Being bullied by other staff members (Moyle, Skinner, Rowe, \& Gork, 2003)

Working with unskilled or inappropriately trained staff (Moyle, Skinner, Rowe, \& Gork, 2003)

Laborious documentation (Moyle, Skinner, Rowe, \& Gork, 2003)

Tensions within role expectations (Moyle, Skinner, Rowe, \& Gork, 2003)

Increased need to be available for overtime (Moyle, Skinner, Rowe, \& Gork, 2003)

Exposure to physical aggression by residents (Dougherty, Preston, Jones, \& Payne, 1992)

Exposure to verbal aggression by residents (Dougherty, Preston, Jones, \& Payne, 1992)

Deficiencies in communication from supervisors (Grieshaber, Parker, \& Deering, 1995)

Factors Considered to be Necessary for Care of Demented Persons

Personal characteristics such as kindness, flexibility, patience, calm manner (Krovach \& Krejci, 1998) 1

Increased amount of training (Krovach \& Krejci, 1998)

Reduced regimentation and routinization (Beck, Ortigara, Mercer, \& Shue, 1999) 1

Presence of a support group for workers (Broughton \& Golden, 1995) 2

Adequate levels of emotional, psychological and moral support from employer

(Kristiansen, Hellzen, \& Asplund, 2006) 


\section{Factors that Increase Job Strain}

Permanent assignment to residents (primary nursing) results in residents becoming overly demanding

(Patchner \& Patchner, 1993)

Tense, distrustful relationships between family members and nurse aides (Grau \& Wellin, 1992)

Presence of conflicting subcultures (religious, ethnic) within the nursing home (Grau \& Wellin, 1992)

Status hierarchy between nurse aides and family members (aides seen as servants) (Grau \& Wellin, 1992)

Racist remarks by family directed at nurse aides (Grau \& Wellin, 1992)

Racist remarks by residents directed at nurse aides (Berdes \& Eckert, 2001)

Being unable to develop an organizational style that keeps the nurse aide out of trouble (Bowers \& Becker, 1992) 1

Cutting corners but not preplanning the cuts (Bowers \& Becker, 1992)

Breaking rules inadvertently or out of desperation (Bowers \& Becker, 1992)

Being concerned about the quality of care provided to the residents (Bowers \& Becker, 1992)

Bundling tasks to accomplish several tasks at once but feeling guilty about it (Bowers, Esmond, \& Jacobson, 2000) 1

Greater workload result in aides more likely to feel burdened (Chappell \& Novak, 1992)

\section{Factors that Reduce Job Strain}

Uniform culture (religious, ethnic) within the nursing home (Grau \& Wellin, 1992)

Family members have cultural connections with nurse aides (Grau \& Wellin, 1992)

Organizational style of the nurse aide that works for them (keeps them out of trouble) (Bowers \& Becker, 1992)

Cutting corners deliberately (pre-planning cuts) (Bowers \& Becker, 1992)

Being selective about which rules are broken (Bowers \& Becker, 1992)

Bundling tasks in order to accomplish several tasks at once (Bowers, Esmond, \& Jacobson, 2000)

Cutting corners in a way that is invisible to supervisors (Bowers, Esmond, \& Jacobson, 2000) 1

Not reporting unacceptable care to supervisors (Bowers, Esmond, \& Jacobson, 2000) 1

Giving the appearance of following orders while doing otherwise (Jervis, 2002a)

Refusal to attend meetings or events (Jervis, 2002a)

Aides who have greater numbers of family members supportive of their work (Chappell \& Novak, 1992) 1

Aides who had fewer individuals living with them in the same household (Chappell \& Novak, 1992)

\section{Most Desirable Aspects of the Job}

Being around/helping elderly people (Berdes \& Eckert, 2001)

Being able to care for/help somebody (Berdes \& Eckert, 2001)

Being a part of a team, with co-workers (Berdes \& Eckert, 2001)

Relationship with residents (Parsons, Simmons, Penn, \& Furlough, 2003)

Feeling valued and needed by residents (Kristiansen, Hellzen, \& Asplund, 2006)

\section{Least Desirable Aspects of the Job}

Low pay (Berdes \& Eckert, 2001)

Emotional distress of being in proximity to people who are in pain or dying (Berdes \& Eckert, 2001) 1

Emotionally demanding job (Monahan \& McCarthy, 1992)

Physically demanding job (heavy lifting) (Berdes \& Eckert, 2001) 3

Distasteful tasks (Lin, Yin, \& Li, 2002) 1

Inappropriate sexual or elimination behaviour (Burgio, Jones, Butler, \& Engel, 1988) 3

Residents who have activity/sleep disturbances (Burgio, Jones, Butler, \& Engel, 1988) 2 
Residents who self injure (Burgio, Jones, Butler, \& Engel, 1988)

Residents who are agitated (Burgio, Jones, Butler, \& Engel, 1988)

Residents who exhibit excess disability (medical condition alone cannot account for the degree of disability observed in the resident(Burgio, Jones, Butler, \& Engel, 1988)

Family members as a source of hostility towards aides (Secrest, Iorio, \& Martz, 2005)

Physical assault by resident (Kristiansen, Hellzen, \& Asplund, 2006)

Verbal assault by resident (Kristiansen, Hellzen, \& Asplund, 2006)

Residents destroying property (Burgio, Jones, Butler, \& Engel, 1988)

Residents spitting on caregivers (Burgio, Jones, Butler, \& Engel, 1988)

Lack of control related to time and decision-making (Secrest, Iorio, \& Martz, 2005)

Inability to attend to details they feel are important (Secrest, Iorio, \& Martz, 2005)

Overwhelmed by noise (Kristiansen, Hellzen, \& Asplund, 2006)

Fatigue (Kristiansen, Hellzen, \& Asplund, 2006)

Feeling insignificant (Kristiansen, Hellzen, \& Asplund, 2006)

Feeling humiliated (Kristiansen, Hellzen, \& Asplund, 2006)

Feeling dissatisfied (Kristiansen, Hellzen, \& Asplund, 2006)

Feeling guilty (Kristiansen, Hellzen, \& Asplund, 2006)

\section{Factors Specifically Pertaining to Increased Job Stress}

Distasteful tasks (Lin, Yin, \& Li, 2002)

Being a foreigner (Lin, Yin, \& Li, 2002)

Too many residents assigned to one nurse aide (Lin, Yin, \& Li, 2002)

Centralized decision making (Grau \& Wellin, 1992)

Sharp divisions of labour across all departments (Grau \& Wellin, 1992)

Frequent, wide ranging complaints from residents and/or their families (Grau \& Wellin, 1992)

Insufficient explanations given to nurse aides by RNs (Ahmed \& Kitson, 1993)

Limited training that does not equip the nurse aide for the responsibilities (Ahmed \& Kitson, 1993)

Performing work that they are not qualified to perform (Ahmed \& Kitson, 1993)

Role ambiguity (Ahmed \& Kitson, 1993)

Status hierarchies between RNs and aides (Ahmed \& Kitson, 1993)

RNs spending much of their time on administrative duties (Ahmed \& Kitson, 1993)

LPNs spending much of their time on medication administration (Anderson, Bailey, Corazzini, \& Piven, 2005) 1

Workload (Ahmed \& Kitson, 1993)

Nurse aides perceive lack of support from supervisors (Ahmed \& Kitson, 1993) 2

Threat of assault by resident (Jervis, 2002b)

Conflicts with residents who have mental illnesses (McGrew, 1999)

Verbal or physical assault by resident (MacPherson, Eastley, Richards, \& Mian, 1994)

Cigarettes as a source of irritation between staff and residents (Jervis, 2002b)

Lack of help during a behavioural crisis (Jervis, 2002b)

Residents who are mentally ill in addition to other co-morbidities (Jervis, 2002b)

Feeling uncertain about whether or not the residents could actually control themselves in certain situations

(Kristiansen, Hellzen, \& Asplund, 2006)

Not attending care conferences or reading care plans (McGrew, 1999)

Conflicts with residents who are addicted to cigarettes (McGrew, 1999)

Aides who perceive lack of rewards at work are more likely to experience burnout (Chappell \& Novak, 1992) 1 
Aides less hardy, more vulnerable to occupational stressors and burnout than RNs

(Harrison, Loiselle, Duquette, \& Semenic, 2000)

Chronic minor assaults (Freyne \& Wrigley, 1996)

Factors Specifically Pertaining to Reduced Job Stress

Feeling confident in and supported by colleagues (Lin, Yin, \& Yi, 2002) 4

On the job training (Lin, Yin, \& Yi, 2002) 2

Shared decision making (Grau \& Wellin, 1992) 1

Tasks and responsibilities overlap within and across departments (Grau \& Wellin, 1992) 1

Aides who receive dementia training less likely to experience burnout (Chappell \& Novak, 1992) $\quad 1$

Aides who receive support for their work from family and friends less likely to

experience burnout (Chappell \& Novak, 1992)

Factors Found to Increase Aide Turnover

Failure of management to recognize social and cultural differences between the aides and the residents and their families (Grau \& Wellin, 1992)

Role ambiguity (Baldwin, Roberts, Fitzpatrick, While, \& Cowan, 2003)

Lack of a defined career pathway (Baldwin, Roberts, Fitzpatrick, While, \& Cowan, 2003) 2

Aides not present at care planning meetings (Banaszak-Holl \& Hines, 1996) 1

Being able to provide care in a way that is like family (Bowers, Esmond, \& Jacobson, 2000) 1

Feeling of being disrespected by supervisors (Bowers, Esmond, \& Jacobson, 2000) 1

Unpredictable absence policies (Bowers, Esmond, \& Jacobson, 2000) 2

Low pay (Bowers, Esmond, \& Jacobson, 2000) 5

Low morale (Bowers, Esmond, \& Jacobson, 2000) 2

High RN turnover (Brannon, Zinn, Mor, \& Davis, 2002) 1

Facility is a training site (Brannon, Zinn, Mor, \& Davis, 2002) 1

Facility is for profit (investor owned) (Brannon, Zinn, Mor, \& Davis, 2002) 2

Evening shift workers (Burgio, Fisher, Fairchild, Scilley, \& Hardin, 2004) 1

Conflicts in relationships between RNs and aides (Jervis, 2002a) 1

Unrewarding role of nurse aide (Jervis, 2002a) 1

Traditional bureaucratic organizational structure (Riggs \& Rantz, 2001) 3

Lack of multi-channelled open-communication (Riggs \& Rantz, 2001) 2

Supervisors symbolically distinguishing themselves from subordinates (Jervis, 2002a) 1

Supervisors responding to all rule infractions with strict discipline (Jervis, 2002a) 2

Lack of problem-solving skills needed to cope with demands (Riggs \& Rantz, 2001) 1

Excessive work load (Riggs \& Rantz, 2001) $\quad 4$

Perception that other employment opportunities are available (Riggs \& Rantz, 2001) 2

Sheer effort and determination to seek a way out of an oppressive lifestyle (Tellis-Nayak \& Tellis-Nayak, 1989)

Written competency examinations (Thorson, 1989) 1

Feeling dismissed, invisible or insignificant (Bowers, Esmond, \& Jacobson, 2003) 2

Supervisors demeaning or humiliating aides (Bowers, Esmond, \& Jacobson, 2003) 1

Implementation of a new program (Eden Philosophy) lead to increased turnover (Coleman et al. 2002) 1

Female gender (Cotton \& Tuttle, 1986) 1

Managerial style authoritarian (Waxman, Erwin, Carner, \& Berkenstock, 1984) 1 


\section{Factors Found to Reduce Aide turnover}

Permanent assignment (primary nursing) (Patchner \& Patchner, 1993)

Uniform culture (religious, ethnic) between nurse aides and residents and their families (Grau \& Wellin, 1992)

Involve aides in care planning meetings (Banaszak-Holl \& Hines, 1996)

Discuss care plans with aides and ask for advice and suggestions (Banaszak-Holl \& Hines, 1996)

Untrained supervisors (Brannon, Zinn, Mor, \& Davis, 2002)

Low RN turnover (Brannon, Zinn, Mor, \& Davis, 2002)

Flatter management structure (less middle management) (Brannon, Zinn, Mor, \& Davis, 2002)

Presence of a union contract governing managerial relations (Brannon, Zinn, Mor, \& Davis, 2002)

Acknowledgement of contributions of nurse aides (Broughton \& Golden, 1995)

Formation of support groups for nurse aides (Broughton \& Golden, 1995)

Relationship with residents (Parsons, Simmons, Penn, \& Furlough, 2003)

Focus on the personal needs of the aides (Riggs \& Rantz, 2001)

Administration and supervisors model effective interactions and respectful communication (Riggs \& Rantz, 2001) 1

Benefits that will decrease personal stressors (flexible scheduling, child care etc.) (Riggs \& Rantz, 2001) 3

Personalized incentives and rewards (Riggs \& Rantz, 2001)

A sense of connection with co-workers (Secrest, Iorio, \& Martz, 2005)

A sense of connection with families (Secrest, Iorio, \& Martz, 2005)

Taking pride in their work (Secrest, Iorio, \& Martz, 2005)

Practicing charity and accumulating virtue (Hsieh \& Su, 2007)

Feeling in control by being conscientious about details (Secrest, Iorio, \& Martz, 2005)

Mutual decision making for policies and practices that directly affect the aides (Secrest, Iorio, \& Martz, 2005)

Pay for coverage of the unit for conference time (Secrest, Iorio, \& Martz, 2005)

Psychological nourishment obtained through solidarity, fellowship, collegial support (Kristiansen,

Hellzen, \& Asplund, 2006)

Monetary rewards including scholarships, tuition fee reimbursement (Sung, Chang, \& Tsai, 2005)

Compassion for residents/personal interest in residents (Sung, Chang, \& Tsai, 2005)

Cleanliness of the facility (Sung, Chang, \& Tsai, 2005)

Adequate staffing (Sung, Chang, \& Tsai, 2005)

Good equipment (Sung, Chang, \& Tsai, 2005)

Initial training program for new aides (Sung, Chang, \& Tsai, 2005)

The work is personally rewarding and fulfilling (Sung, Chang, \& Tsai, 2005)

Callous detachment... a passionless game (Tellis-Nayak \& Tellis-Nayak, 1989)

Cynicism (Tellis-Nayak \& Tellis-Nayak, 1989)

Nursing homes with reward based administration climate (Anderson, Corazzini, \& McDaniel, 2004)

Nursing homes with higher levels of communication openness (Anderson, Corazzini, \& McDaniel, 2004)

Administration that emphasizes relationship and concern for employees (Anderson, Corazzini, \& McDaniel, 2004) 1

Administration that fosters self organization (people mutually adjust behaviours to cope with changing external environmental demands (Anderson, Corazzini, \& McDaniel, 2004)

Homes with higher daily aide hours per resident have lower annual turnover

(Anderson, Corazzini, \& McDaniel, 2004)

Overall job satisfaction (Cotton \& Tuttle, 1986)

Increasing age of employee (Cotton \& Tuttle, 1986)

Tenure of employee decreases turnover (Cotton \& Tuttle, 1986) 
Expectations are met (Cotton \& Tuttle, 1986)

Increased diversity of training methods (workshops, seminars, videos etc.) (Grant, Kan, Potthoff, \& Ryden, 1996) 1

\section{Findings Related to Burnout}

Aides are at the higher risk for burnout when compared to LPNs or

RNs (Astrom, Nilsson, Norberg, \& Winblad, 1990)

Higher rates of burnout for morning shift workers (Burgio, Fisher, Fairchild, Scilley, \& Hardin, 2004) 1

Exposure to physical and psychological aggressive behaviour by residents (Evers, Tomic, \& Brouwers, 2002) 1

Aides experience more burnout than RNs (Hare \& Pratt, 1988)

Findings Related to Empathy

Aides caring for demented patients have lower mean empathy scores than RNs caring for demented patients (Astrom, Nilsson, Norberg, \& Winblad, 1990)

Cognitively intact residents who perceive empathy from nurse aides have reduced rates of depression

(Hollinger-Samson \& Pearson, 2000)

Difficulty being empathetic when it is believed that an assault is purposeful and resident knows what he or she is doing (Jervis, 2002b)

Reliance on inaccurate or stigmatizing folk conceptions of mental illness (Jervis, 2002b)

\section{Factors Found to Increase Absenteeism}

Primary nursing (permanent assignment) results in significantly more absenteeism

(Burgio, Fisher, Fairchild, Scilley, \& Hardin, 2004)

Morning shift workers (Burgio, Fisher, Fairchild, Scilley, \& Hardin, 2004)

Working full time (Chappell \& Novak, 1994)

Aides caring for multiple residents with gross mental impairments (Chappell \& Novak, 1994) 1

Aides caring for constantly restless residents (Chappell \& Novak, 1994)

Aides caring for multiple residents with mental illnesses (Chappell \& Novak, 1994)

Factors Found to Reduce Absenteeism

Permanent assignment to residents (primary nursing) (Patchner \& Patchner, 1993)

Team nursing would lead to more discussions about absenteeism and

lateness (Yeatts, Cready, Ray, DeWitt, \& Queen, 2004)

\section{Discussions Regarding Primary nursing versus Team nursing}

Primary nurses may become over-involved or over-identified with a patient (Bowers, 1989)

Primary nursing may lead to disagreements about care strategies (Bowers, 1989) 1

Primary nursing may lead to divisions within the nursing team (Bowers, 1989) 1

Primary nurses may be unsure of the boundaries of their work (Bowers, 1989) 1

Primary nursing may lead to decreased communication within the nursing team (Bowers, 1989) 1

Primary nursing (permanent assignment) residents prescribed more medications

(Burgio, Fisher, Fairchild, Scilley, \& Hardin, 2004)

Primary nursing residents prescribed more psychotropic medications

(Burgio, Fisher, Fairchild, Scilley, \& Hardin, 2004)

Primary nursing residents received higher ratings for personal appearance and hygiene

(Burgio, Fisher, Fairchild, Scilley, \& Hardin, 2004) 
Same residents day after day magnify tensions (Foner, 1994)

Team nursing leads to improved interpersonal relationships between nurse aides

(Yeatts, Cready, Ray, DeWitt, \& Queen, 2004)

Team nursing leads to better coordination of resident care (Yeatts, Cready, Ray, DeWitt, \& Queen, 2004)

Team nursing leads to increased information sharing (Yeatts, Cready, Ray, DeWitt, \& Queen, 2004)

\section{Factors Negatively Affecting Morale}

Nurse aides are not defined as nurses (Advisory Committee on Health Human Resources, 2000)

Low occupational status (Berdes \& Eckert, 2001)

Low wages (Berdes \& Eckert, 2001)

Low opportunities for advancement (Berdes \& Eckert, 2001)

Job instability (Berdes \& Eckert, 2001)

Physical difficulties of short staffing (Bowers, Esmond, \& Jacobson, 2000)

Supervisors disrespectful of aides (Jervis, 2002a)

Supervisors not committed to keeping aides on staff (Jervis, 2002a)

Constant reprimands (Jervis, 2002a)

Offensive or disturbing language from residents (Ramirez, Teresi, \& Holmes, 2006)

Racial abuse from residents (Mercer, Heacock, \& Beck, 1993)

Administrators and supervisors perceived as racially biased (Mercer, Heacock, \& Beck, 1993)

Being required to attend support groups (Ramirez, Teresi, \& Holmes, 2006)

Not feeling valued by employer (Kristiansen, Hellzen, \& Asplund, 2006)

Feeling that the job is insignificant (McGillis-Hall \& O’Brien-Pallas, 2000)

Elaborate extended family networks necessary to assist with finances and

childcare (Mercer, Heacock, \& Beck, 1993)

Having to work extra shifts or take a second job to cover basic finances (Mercer, Heacock, \& Beck, 1993)

Feeling inadequately trained for the job (Mercer, Heacock, \& Beck, 1993)

Absenteeism of other workers (Mesirow, Klopp, \& Olson, 1998)

Lack of teamwork (Monahan \& McCarthy, 1992)

The experience of psychological aggressive behaviour (Evers, Tomic, \& Brouwers, 2002)

Aide positions have less motivating potential than LPN positions (Brannon et al. 1988)

Factors affecting basic policy questions about regulation, supply, deployment and movement of nurse aides Absence of a national (Canadian) data bank (Advisory Committee on Health Human Resources, 2000)

Note: To conserve space, only the first author is listed 
Aides collectively feel dissatisfied with organizational factors that inhibit them from providing excellent care $20.1 \%$

The supervisory style is generally hierarchical, demeaning and dismissive

Aides collectively feel undervalued and unappreciated

Lack of financial compensation and rewards shape general job dissatisfaction

Aides lack the training and problem-solving skills necessary to cope with demands

Caring relationships and/or connectedness between aides and residents or aides and families, and collegial connections are very important motivational factors that reduce turnover rates and increase quality of care 